Article

\title{
The Monetary Measurement of Flood Damage and the Valuation of the Proactive Policies in Sicily ${ }^{+}$
}

\author{
Maria Rosa Trovato * and Salvatore Giuffrida ${ }^{(i)}$ \\ Department of Civil Engineering and Architecture, University of Catania, 95125 Catania, Italy; \\ sgiuffrida@dica.unict.it \\ * Correspondence: mrtrovato@dica.unict.it; Tel.: +39-333-436-8621 \\ + This paper is an extended version of our paper Giuffrida, S.; Ferluga, G.; Trovato, M. R., Flood Risk and Land \\ Resilience: a Socio-Systemic Approach to valuation. In Proceedings of the 19th IPSAPA/ISPALEM International \\ Scientific Conference: The Turning Point of the Landscape-cultural Mosaic: Renaissance Revelation Resilience, \\ Piccinini, L. C. et al., (Eds.); 2016, pp. 29-41.
}

Received: 16 March 2018; Accepted: 19 April 2018; Published: 22 April 2018

\begin{abstract}
Although floods, as well as other natural disasters, can be considered as relevant causes of intra-generational inequalities, frequent catastrophes and the resulting damage to the territory can be seen as a consequence of a generalized indifference about future. Land protection is one of the societal issues typically concerning inter-generational solidarity, involving the administrative system in the implementation of proactive policies. In the last three decades, the widespread demand for subsidiarity has made local communities more and more independent, so that attention to the long-term effects-typically concerning the territorial system as a whole at geographical scale- has been dispersed, and the proactive policies that come from the central government have become more ineffective. Regarding the case of the 2009 flood in the Fiumedinisi-Capo Peloro river basin in North Eastern Sicily, we propose an economic valuation of the land protection policy. This valuation, compared to the cost of recovery of the damaged areas, can provide helpful information on the decision-making process concerning the trade-off between reactive and proactive land policy. The economic value of land protection was calculated by means of the method of the imputed preferences, to obtain a real measure of the social territorial value from the point of view of the harmony between social system and environment. This method consists of an estimate based on the attribution of the expenditures according to the importance of the different areas. Since the value of land protection has been calculated by discounting the expenditures stream, some considerations about the economic significance of the proactive policy are referred to the role played by the social discount rate in the inter-temporal economic calculation.
\end{abstract}

Keywords: proactive policies; land protection; inter-generational solidarity; social system; environment; sustainability; cost-benefits Analysis; imputed preferences; imputed expenditures; GIS; social discount rate

\section{Introduction}

This study is framed within the more general issue of the economic valuation of the policies of land protection from flood risk, with specific reference to the flood that damaged the Fiumedinisi-Capo Peloro river basin in North Eastern Sicily in 2009 [1].

According to the general definition of risk, the damaging effects of natural disasters can be considered as the result of three converging determinants: (1) climate change and its local effects in terms of climatic disorder, as responsible for hazard; (2) the progressive modification of the balance between natural system carrying capacity and urbanization, as responsible for vulnerability; 
(3) progressive population growth, the consequent increase in built volume and real estate value and the infrastructure development as responsible for exposure.

The climate change problem cannot be solved even in the long term, as that would require a transition to a different development pattern of the whole of humankind. Therefore adaptation has become the only possible perspective. As a consequence, major efforts are needed to achieve a significant reduction of vulnerability, especially in more exposed areas.

The structural scarcity of funding and the resulting decisions pose relevant questions of inter/intra-generational justice. According to Tremmel ([2], p. 5), justice between generations needs to be referred to the adequate scale (global, continental, national, etc.), which, in this case, is regional; justice within generations needs to be specified as: social (rich/poor people), international, between genders (men/women) etc., and in this case as territorial, i.e., referred to the value of the land resources included in the involved area.

Inter-generational solidarity is the commitment of one generation to another to: guarantee the freedom of choice about the availability of natural and cultural resources; preserve the quality of the planet in order to hand it down to the next generations in the same or better condition; ensure the access right to the legacy of past generations and preserve it for future generations as well.

The decision makers balance inter/intra-generational solidarity by arranging the fair combination of reactive and proactive policy. According to Torjman ([3], Figure 3), "Reactive policy emerges in response to a concern or crisis that must be addressed-health emergencies and environmental disasters are two examples. Proactive policies, by contrast, are introduced and pursued through deliberate choice."

In general, a proactive land protection policy is the set of actions and interventions aimed at reducing the vulnerability of a defined risky area, according to the balance between the risk degree and the expected costs.

As a consequence, reactive policies enact intra-generational solidarity. The fair combination between proactive and reactive policy needs to be supported by explicit evaluations involving appraisal and assessment procedures aimed at encouraging people's awareness and participation in the decision process.

To date, many approaches, methods and tools have been developed for the monetary appraisal and qualitative assessment [4-6] in the field of prevention; among them, the approach to "avoided damage" [7], which is the cost for preventing a community from being blemished by a damage of at least equal value. In particular, Pimentel et al. [8] assume it refers to the benefit of biodiversity estimated as a percentage (5\%) of the GDP, the monetary value of the protection services.

Kremen et al. [9] apply the opportunity cost to incentivize the preservation of the rain forests in Madagascar, and argue that the deforestation exacerbation is caused by the financial benefits from the industrial timber production being larger than the forest conservation benefits.

Merlo and Croitoru [10] approach the Total Economic Value (TEV) of the Mediterranean forests by including in their estimate the public goods and externalities they provide [11-13].

Finally, Hansoon et al. [14] propose an original perspective, somehow contrary to the concept of exposure and overcoming the "avoided damage" approach, as: "The impact of disasters on society depends on the affected country's economic strength prior to a disaster. The more large-scale the disaster and the smaller the economy, the more significant is the impact. This is clearly visible in developing countries, where weak economies become even weaker afterwards." This approach suggests that it is necessary to overestimate the mere economic value of buildings and infrastructures in order to prevent the affected community from finally falling into the trap of poverty, thus including it in the estimates of social value.

Kramer et al. [15] integrate the ecological value in the economic estimate of the park projects aimed at preventing flood damage in Madagascar, by comparing "with" and "without park" cases. 
Territory is a complex of private goods, public goods and common goods with different "local-global" characterization; the literature on economic evaluation of territory has highlighted different dimensions of its economic value [16].

In general, economic value relates to the system of individual and aggregate preferences, regardless of the need for assessments to be expressed in monetary terms.

With reference to the above-mentioned flood that occurred in the Fiumedinisi-Capo Peloro river basin, the paper tries to provide the evaluation of the adequacy of the current territorial policy in Sicily, by comparing the proactive efforts to the reactive actions.

Some elements concerning the risk profile of the area, the damages and the costs occurred for the emergency management and rehabilitation are reported and compared to the public expenditure for the risk mitigation.

Now, whereas in the ground of economic analysis (CBA), expenditure are assumed as cost, in the ground of appraisal and assessment, according to the concept of "imputed preferences", which the method of "defensive expenditure" comes from, spending can be assumed as a reference for the valuation of a good; the expenditures for defensive actions (mitigation costs, monitoring and assessment costs for prevention from further degradation) are considered as the monetary measurement of the minimum value of an environmental good or service.

Technical and political-economic choices determine different ways of implementing both inter-generational solidarity (the fair amount of public spending compared to the probable future rehabilitation costs) and intra-generational solidarity (the territorial allocation of the spending).

In the ground of inter-generational solidarity, based on the Regional Government balance sheet observed within a defined time span, the annual budget for land protection has been calculated by selecting the expenditures of the Departments mainly involved in prevention; a Discounted Cash Flow Analysis has been carried out in order to compare the present value [17] of such stream to the emergency management and rehabilitation costs; based on a synthetic literature review concerning the approach to the social discount rate; some comments follow the results achieved by implementing the most significant of such approaches.

In the ground of intra-generational solidarity, assuming the protection expenditure as a measure of the land security value, the value attributable to the examined basin has been calculated by performing a specific spatial analysis carried out by means of Geographical Information System (GIS) functions aimed at taking into account the relative importance of the examined river basin along with the others of the region.

The two features (amount and allocation) converge to calculate the imputed expenditure, that is the monetary value of security whose adequacy is assessed by comparing it to the cost for rehabilitation under different hypothetical conditions

\section{Materials}

\subsection{Territorial Framework}

The province of Messina consists of a $3247 \mathrm{~km}^{2}$ area in North Eastern Sicily, bordering South on the province of Catania and West on the province of Palermo. Its territory extends from the Peloritani to the Nebrodi mountain chains, and is delimited North by the Tyrrhenian Sea and East by the Ionian Sea. On 1 October 2009, the Ionian coast, comprising the Municipalities of Messina, Scaletta Zanclea and Giardini Naxos, was hit by a violent flood that caused damage to the villages of Giampilieri, Giampilieri Superiore, Giampilieri Marina, Molino, Altolia, Briga, Briga Superiore, Briga Marina, Pezzolo and Santa Margherita Marina in the Municipality of Messina, the villages of Scaletta Marina, Scaletta Superiore, Guidomandri Marina, Guidomandri Superiore in the Municipality of Scaletta Zanclea, the villages of Itala Marina, Itala Centro, Borgo, Mannello and Croce in the Municipality of Itala, and the Municipalities of Alì and Alì Terme (Figure 1). The flood caused landslides, overflowing of rivers and streams, flooding of residential, commercial and industrial settlements, the interruption 
of the transportation infrastructures (roads, highway and railway), and resulted in 31 dead, 6 missing, 122 injured and the evacuation of 2019 people.

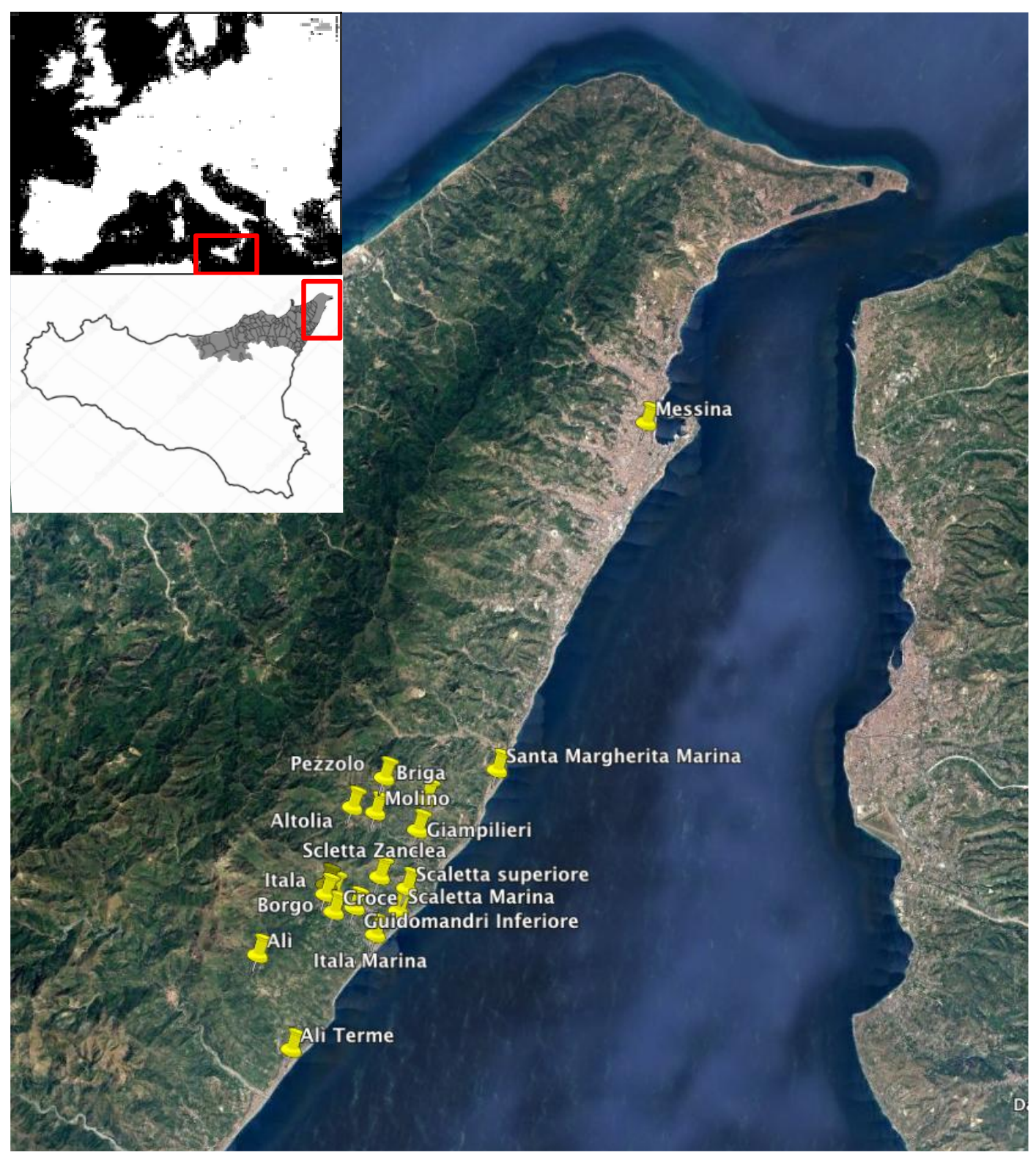

Figure 1. Territorial frame and identification of the main urban centres hit by the flood.

\subsection{Hazard: East Sicily from the Climatic Point of View}

The rainfall and thermometric data characterize Sicily as a "warm temperate with a prolonged summer season and mild winter" region. The average winter temperature is higher than 5 degrees Celsius, while the average minimum temperature is barely lower than 0 degrees Celsius.

Sicily has a characteristic hilly region climate with an average temperature of 16 degrees Celsius; the warmest month is August and the coldest January.

The sunniest month is June (14.6 h daylight), while the annual minimum is in December $(9.4 \mathrm{~h}$ daylight). Rainfall is lowest in July (with lowest water flow in August) and highest in December.

Rainfall ranges from $0 \mathrm{~mm}$ in July to over $76 \mathrm{~mm}$ in December, with an annual average of $540 \mathrm{~mm}$, which is lower than the annual national average of $970 \mathrm{~mm}$. With 70 rainy days a year, Central Sicily can be considered as a medium-intensity rain zone (Figure 2). The characterization of drought 
conditions, whose persistence causes the deterioration of the soil characteristics, is an important aspect of climatology [18].

The 2009 Messina flood began on the evening of 1st October 2009 and lasted all night until the morning, causing damage to an area that, despite its articulated topography, is heavily urbanized.

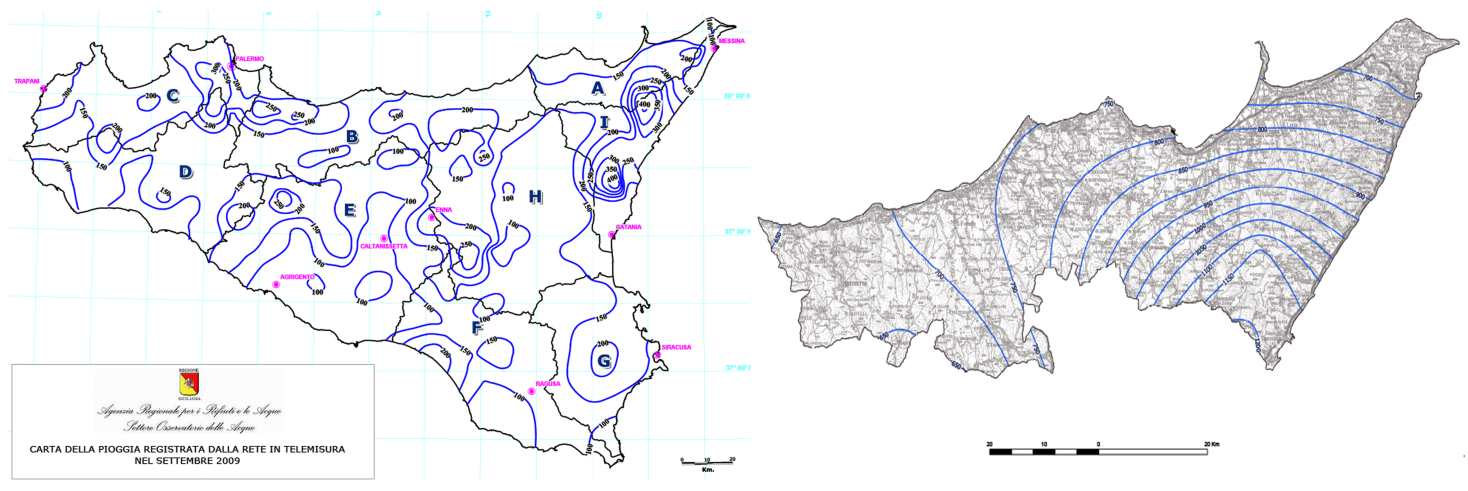

Figure 2. The isohyets in September 2009 and in the year 2009 [19].

According to the Civil Protection Department data, in some of the damaged areas, the rainfall record is $220 / 230$ in 3-4 h. The cumulative deviation from the average long-term rainfall record in Sicily in 2008 was negative (Figure 3A), while the one in 2009 was positive (Figure 3B).

The average monthly rainfall record in Sicily in the period 2008-2009, compared to the long-term data, is higher than the average reference value in the period 1921-2005 (Figure 3C,D). Therefore the flood event in October 2009 can be considered as exceptional. The values of the isohyets in September 2009 indicate the province of Messina as the territory most affected by rainfall (Figure 4).

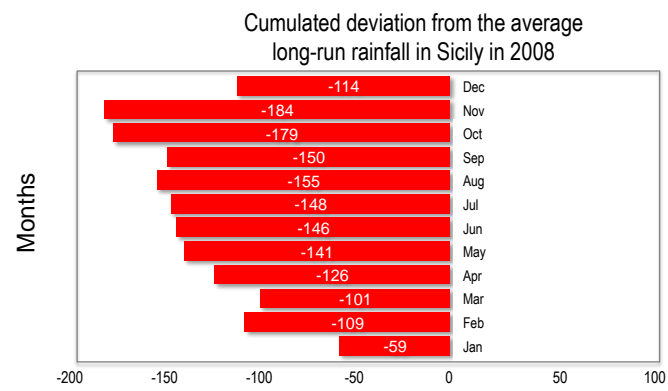

$\mathrm{C}$

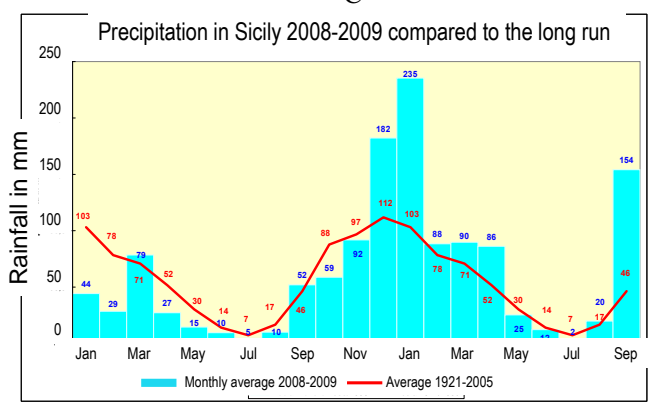

B

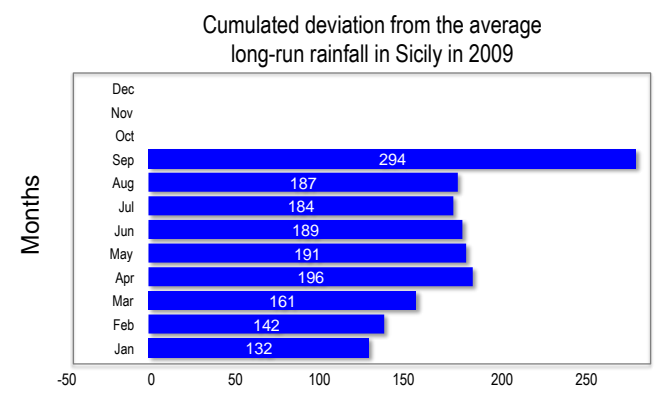

$\mathrm{D}$

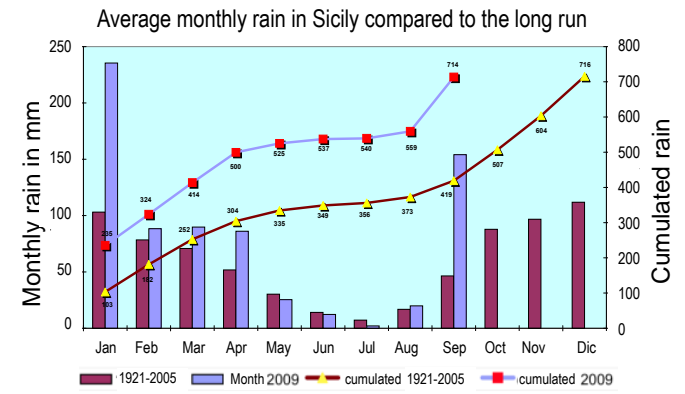

Figure 3. (A) The cumulative deviation from the average long-term rainfall record in Sicily in 2008-2009. (B) Rainfall in Sicily in 2008-2009 compared to the long-term data; (C) Monthly rainfall in mm compared to the long-term data. (D) Average monthly rainfall in Sicily compared to the long-term data [19]. 
Precipitation regime continued to report high level of flood risk in the studied area until now as displayed in Figure 4, which refers to the situation in 2017 [20].
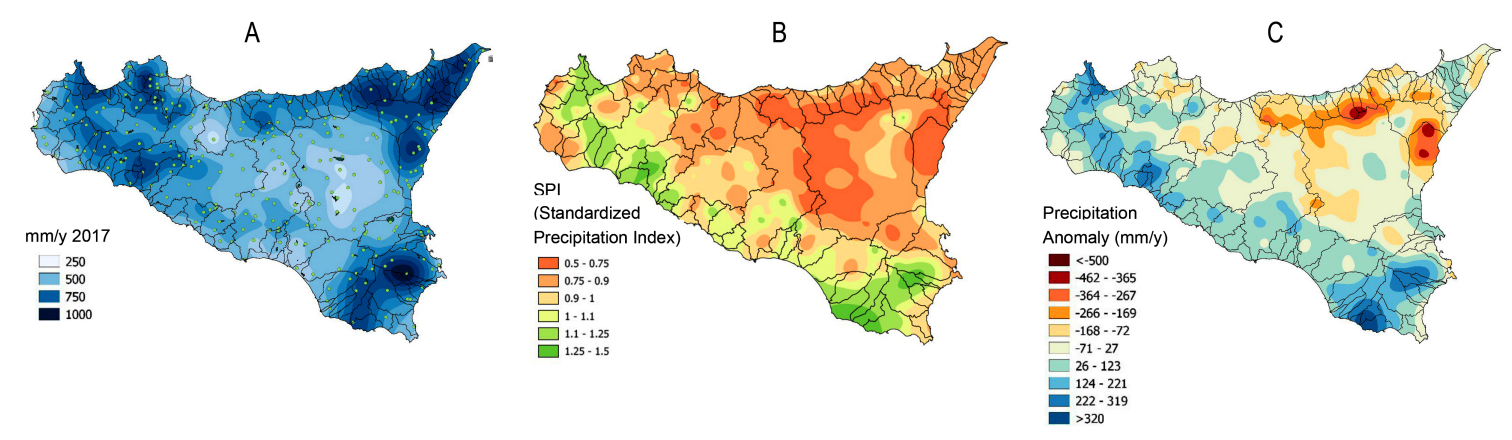

Figure 4. (A) Precipitation 2017 (mm/year); (B) standard Precipitation Index classes; (C) Precipitation anomaly (mm/year).

\subsection{Identification and Analysis of Risky Areas}

The disaster situation is described by the Detailed Plan for the Hydrogeological Asset [21], which maps the areas characterized by risk and vulnerability of their urban centres; safeguard standards are defined as well.

As a consequence of further landslides, in February 2010 the entire area was declared a hydrogeological high-risk area. Different risk and hazard degrees have been distinguished according to the number and extension of instabilities for each of the five municipalities hit by the flood:

- Very high hazard areas (P4) with 69 instabilities for a total surface of 157.91 ha;

- High hazard areas (P3) with 230 instabilities for a total surface of 196.67 ha;

- Medium hazard areas (P2) with 151 instabilities for a total surface of 304.27 ha;

- Moderate hazard areas (P1) with 108 instabilities for a total surface of 56.49 ha;

- Low hazard areas (P0) with seven instabilities for a total surface of 11.20 ha.

Four degrees of risk have been defined as follows:

- R1-moderate risk: social, economic and environmental damage is low;

- R2-medium risk: probability of minor damage to buildings, infrastructure, environment, not including human safety, use and economic activities;

- R3-high risk: envisaged problems to human safety; damage to buildings and infrastructures including their use, and causing hold-up of socio-economic activities and severe damage to the environment;

- R4-very high risk: envisaged loss of human lives and severe injuries to persons; severe damage to buildings, infrastructures and the environment and socio-economic activities destruction.

Figure 5 synthesizes only the instabilities and the risk degree.

\subsection{Funding}

As a consequence of the state of emergency, which was declared the day after, several national and regional regulatory measures ruled the funding for: expenses for first aid interventions, assistance to the population and identification of damage; restoration and reconstruction of destroyed and damaged properties; housing for homeless families; contributions to businesses located in damaged areas or buildings; social security, welfare and suspension of tax obligations and payments by residents in the province.

The Italian Government requested the intervention of the European Union Solidarity Fund (FSUE), which allocated $€ 139$ million as follows: 
- A total of $€ 60$ million to the Delegate Commissioner (Article 4 OPCM No 3815/2009), divided into: $€ 20$ million to the Sicilian Region under the FAS 2000/2006 and PAR-FAS 2007-2013 funds; $€ 20$ million from the funds of the Ministry of the Environment and the Protection of Territory and the Sea; $€ 20$ million to the Civil Protection Fund specifically supplemented by the Ministry of Economy and Finance;

- A total of $€ 45$ million art. 9 OPCM n. 3865/2010 from the PAR-FAS fund 2007-2013, approved by the Resolution of the Sicilian Regional Council No 315 12-08-2009, intended for the continuation of urgent initiatives;

- A total of $€ 10$ million to the Delegated Commissioner, President of the Sicilian Region;

- A total of $€ 24$ million for assistance to the population.

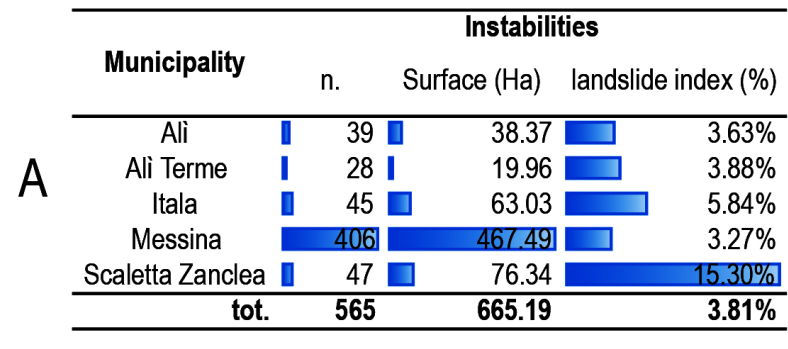

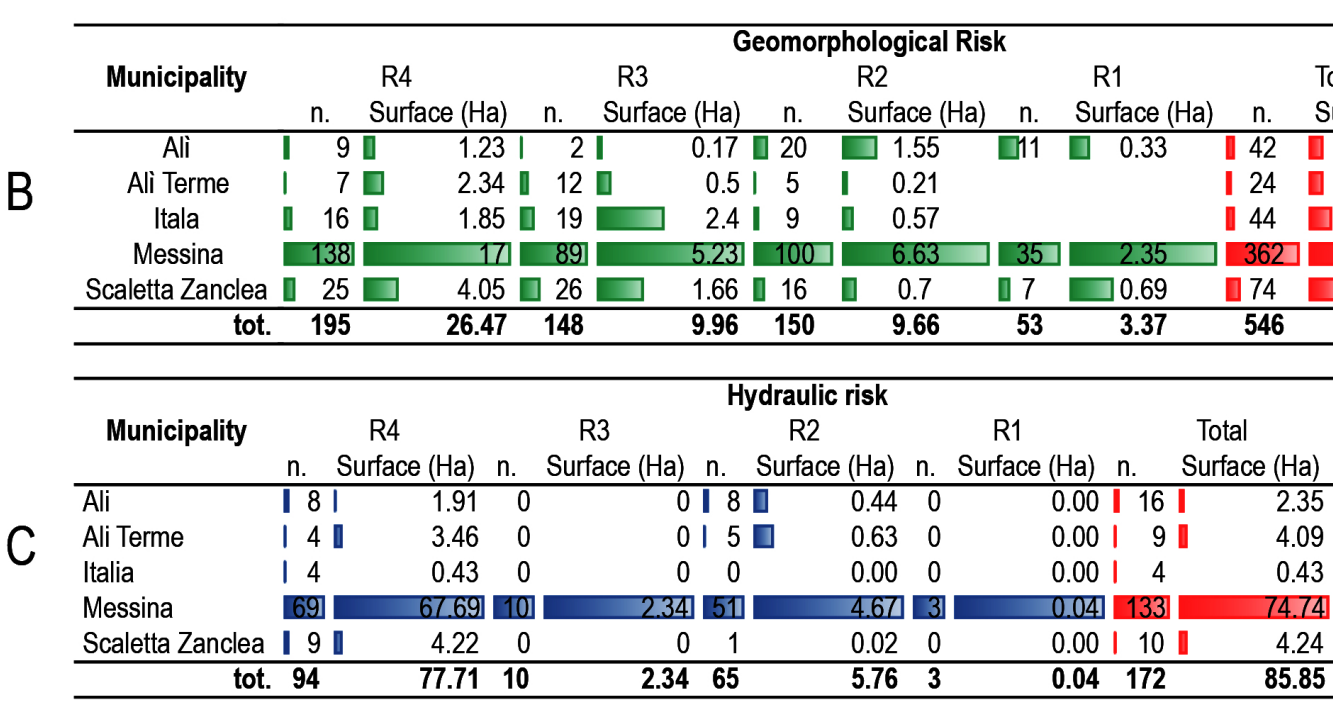

Figure 5. Synthesis of the entity and extension of instabilities and risk in each of the municipalities of the damaged area: (A) Instabilities (landslide index is a percentage than the whole municipality territorial area); (B) Geomorphological Risk; (C) Hydraulic Risk.

Additional $€ 181$ million (Article 1, paragraph 1 OPCM 3886/2010) came from the financial resources allocated to the Municipalities of the Province of Messina and broken down by the Program Agreement signed on 30/04/2010 by the Sicilian Region and the Ministry of "Environment and the Protection of Territory and the Sea" (which includes interventions on the entire Sicilian territory for $€ 304.3$ million). This amount is transferred to the special account of the President of the Sicilian Region Delegated Commissioner, excluding $€ 24$ million for the interventions to be carried out in Giampilieri, and $€ 18$ million allocated to interventions in the town of San Fratello, which are managed by the Delegated Commissioner, President of the Sicilian Region.

The $€ 320$ million Action Program includes:

- $€ 20$ million for reimbursements to the population and production activities;

- $€ 25$ million for repayment for damaged buildings;

- $€ 10$ million for housing construction; 
- $\quad € 15$ million for urbanization works and network facilities;

- $€ 22.4$ million for assistance to the population and management of the Commissioner structure;

- $€ 15.4$ million to the various institutions for the expenses of the first emergency phase;

- $\quad € 212.2$ million for security measures.

\section{Methods}

\subsection{Generalities}

According to the logic of Discount Cash Flow Analysis or Cost-Benefit Analysis, the balance of proactive and reactive policies is a choice problem between current and certain protective interventions, and future and probable recovery interventions. This choice depends:

- On technical function allowing us to foresee in which extent current prevention works will reduce the future expenditures;

- On probability of the future expenditures;

- On social discount rate (SDR), i.e., inter-generational degree.

In such a logic: the public proactive expenditure is considered a cost to be added to the discounted recovery cost related to the probability of catastrophe; benefits come from the technical function allowing us to calculate the avoided damages and loss of human life. Based on such information it is possible to address the problem by calculating the trade-off between:

- Prevention and recovery expenditures;

- Increase (or decrease) in SDR and decrease (or increase) of prevention measures expenditures;

- Increase (or decrease) in probability of catastrophe and increase (or decrease) in prevention measures expenditures.

Instead, this study is framed in the discipline of appraisal and assessment-typically concerned with a prescriptive or normative approach - and aims at providing judgement about the adequacy of the public expense for proactive policy by comparing the cost incurred for recovery to the monetary measurement of the value of safety policies.

Assessment shall use comparison, and where appropriate-typically with no market—it resorts to the economic category of cost, according to the form of economic aspect of the "production cost" or "reproduction cost", so that the value of a good or service can be assumed to be equal to the expenses occurred to (re-)produce it.

From within such a disciplinary area-in the absence of a trade-off function between risk prevention measures and avoided recovery cost-we assume the public expense for risk prevention measures as the real reference for the monetary measurement of the value attributed to territorial protection by regional community. Such an assumption is consistent with the method of imputed preferences [22].

This investigation can be useful for expressing a value judgement on the adequacy of public expense in the field of territorial protection. Now, public expenses are objective data, whether its adequacy comes from a judgement according to technical (probability) and political-economic (solidarity) matters.

\subsection{The Imputed Preferences}

The monetary measure of the value of territory from the point of view of security and landscape harmony may be calculated by applying the method of the imputed preferences, which means by calculating the expense incurred by the social community for the protection of territory from catastrophes. 
This expense is delivered annually to finance the activity of the local government for this purpose, and therefore the Net Present Value of this Cash Flow is assumed as the economic-monetary value of territory from the point of view of the local (regional) community.

NPV varies according to the discount rate, which depends on the temporal social preference rate, indicating the inter-generational solidarity degree.

Therefore we may conclude that the whole social system expresses:

- A certain degree of intra-generational solidarity, shown by the entity of public expense and its territorial allocation;

- A certain degree of inter-generational solidarity, shown by the social discount rate.

In the proposed exemplification we have assumed that the political and economic-productive sub-systems show a shorter perspective than the anthropic and cultural sub-systems, and this is confirmed by the inadequacy of the proactive policies to face the impact of the 2009 flood in the most unstable territories of North Eastern Sicily, which are characterized by high acclivity.

The methodological consequences of such premises concern the choice of the procedure for the comparison of the expenditures for proactive policy to the public cost for the recovery of the damaged areas.

The approach is based on the imputed preferences that, then according to the defensive expenditures method, can be considered as an objective monetary measurement of the value of land safety and, at the same time, the minimum monetary value. In fact, it does not take into account the value of dead and injured people, and the economic losses due to the stopping and the successive reduction of production and commerce.

Such an unbridgeable gap between cost and value highlights the importance of politics and proactive policies, highlighting the inadequacy of the methods based on the individual preferences, such as the hedonic price approach, and, on the trade-off, overestimating the concept of utility that is unable to compare the losses to any possible gain in return.

Furthermore, an approach based on individual preferences-such as the contingent valuation method - cannot be significant in cases in which valuations need a broad awareness of the complexity of natural system as a whole, and a "collective rationality arising in argumentative and conversational contexts" $[23,24]$ based on relations, interdependence, sharing information and reasoning, which are the premises for the arise of social systems.

Arrow et al. [25] and Bresso [26] criticized the contingent valuation approach about the real capability of the stated preferences to capture the complex articulation of the relevant value contents involved in the decision processes.

The specific characteristics of the territory damaged by the flood have been taken into account both by imputing different quotas of the public expenditure for prevention, and by ranging the social discount rate according to: 1 . the importance of the different municipalities; 2 . different scenarios indicating different sensitivity to the inter-temporal preferences, inter-generational ethics and level of sustainability.

The Discounting Cash-Flow Analysis approach involves the social discount rate, also known as Social Rate of Temporal Preference (SRTP), as relevant variable for inter-generational solidarity: the higher the SRTP the lower the economic value, and vice-versa.

\subsection{The Inter-Temporal Solidarity and the Approaches to the Social Discount Rate}

A disaster can be considered as the occurrence of a sudden and large-scale adversity disrupting the basic fabric and the normal functioning of a community, or an event, or a series of events, causing victims and/or damages and losses of properties, infrastructures, services and livelihoods. An exceptional climatic weather event, such as the one that can cause a flood, can break down and destroy the basic components of a territory by deeply altering its layout. 
In this case, the evaluation process supports the ex-post evaluation to quantify the damage caused by the event (namely the loss of value of the components of the damaged areas, and the restoration and mitigation actions), but it can also support the ex-ante evaluation of actions for disaster prevention and management, which are instrumental for outlining proactive policies based on the information infrastructures $[27,28]$.

In both cases, since the evaluation process involves actions that develop over different time spans, a discount process needs to be carried out on the basis of an appropriate social discount rate.

The choice of the social discount rate (SRTP) can be made on the basis of various approaches that indicate a different sensitivity to the inter-temporal preferences, inter-generational ethics and level of sustainability. Accordingly, the choice of the social discount rate is a crucial stage of the evaluation path, both in cases of reconstruction and prevention.

Over the last few years, as a consequence of the increasing importance of the environmental issue - specifically, global warming — and in the perspective of sustainability, the scientific community has proposed new approaches and specific econometric algorithms to support the determination of the social discount rate, in order to be able to capture and characterize the inter-generational dialectics in the field of public goods and service value, based on a range of sustainability approaches according to different visions. The approaches in literature can be grouped into descriptive, prescriptive and empirical.

The descriptive or positive approach supposes SRTP is determined on the basis of the markets' interest rates analysis, and assumes values greater than zero [29-32]. It can be calculated by starting from the Ramsey formula (1928), which optimizes inter-temporal choices based on the maximization of an objective function combining in which the current utility $U_{0}$ is given by integrating the exponential function of the discounted utility $e^{-\rho t} U$ with the level of consumption $C$ at the time $t$ within the time horizon $T$, at the rate of inter-temporal pure preference $\rho$,

$$
U_{0}=\int_{t=0}^{T} e^{-\rho \cdot t} U[C(t)] d t
$$

The prescriptive or regulatory approach, sometimes referred to as the "ethical approach", supposes SRTP is determined based on ethical motivations, and can be set to zero or less than zero [33-39]. SRTP is defined on the basis of the "Equation Ramsey" after Frank Ramsey, in which $\rho$ and $\theta$ (the elasticity of the marginal utility) are decided and normally chosen in relation to ethical considerations, and in particular $g_{C}(t)$ (the expected rate of growth of per capita consumption-income), identified on the basis of empirical observations regarding the growth of consumption (i.e., it is a function of technological progress and the accumulation of resources in the country), determines SRTP at a certain time.

The empirical approach, which introduces uncertainty and risk, supposes that SRTP is determined on the basis of studies of the behavior of individuals who point out the need to adopt declining rates when the temporal horizon is farthest in time, following a more flexible, hyperbolic or quasi-hyperbolic —not exponential—-trend of the discount factor over time [40-59]. Gollier [50,53,60] suggests the introduction of a declining discount rate, to take into account the uncertainty that characterizes the growth rate $g_{C}(t)$, and the index of aversion to risk; Fisher and Krutilla [40] suggest taking into account the expected variation of the willingness of individuals to pay (WTP) for certain public goods and services; Weitzman $[41,43,45]$ suggests taking into account the variation of the environmental cost, and the variation of the ratio between income growth and the perception of environment as luxury good.

It is possible to find out that, despite considerable scientific efforts, currently the values of the social discount rate are different within the Euro Zone; this choice is discretionary to the countries, depending on the different levels of wealth and a different environmental sensitivity and inter-generational ethic [61]. 
The European Commission currently recommends assuming as social discount rate: the one obtained as a benchmark for financial analyses in the member states, with a range of values between $5.5 \%$ and 3.5\% [61]; however it admits different rates, whose use can be justified by specific socio-economic conditions.

The values of the social discount rate proposed by the European Commission are greater than zero and therefore they refer to a descriptive or positive approach, albeit in countries such as the United Kingdom the use of the digressive declining approach (such as the social discount rates declining by "steps" [62,63], which refers to an empirical approach including uncertainty and risk) has been introduced.

Within the Euro Zone, it is possible to find different approaches with different types of assessments of the effects of floods and the interventions both for reconstruction and prevention; such variety suggests multiple interpretations of the relationship between value and time.

Some of these issues have been utilized in order to provide different scenarios and a range of values estimated as support of the proactive land policy in case of flood.

\subsection{The Calculation Pattern}

As anticipated, this contribution aims at comparing the adequacy of the expense for disaster prevention to the cost for the damage recovery reconstruction, in order to support the decision makers' choices between proactive and reactive policies.

According to the imputed preferences approach, the expenditure for prevention can be considered as the minimum value attributed by the settled community to the land-environmental system. Therefore the value of the river basin damaged by the flood has been calculated by discounting the stream of the annual expenditure incurred by the Regional Government that can be attributed to the geographical area hit by the flood.

The model can be sampled as follows:

$$
V_{e}=\int_{0}^{T} e^{-r t} C F(t) d t
$$

where:

- $\quad V_{e}$ is the Net Present Value of the area calculated according to the imputed preference;

- $\quad T$ is the assumed time span;

- $C F$ is the stream (Cash Flow) of the public expenditure that is function of $t$;

- $t$ is time (years).

$C F$ is the part of the overall public expenditure to be imputed to the damaged area. Each of the different Public Administration Departments dealing with welfare has a different degree of responsibility for land protection, therefore for each Department only the related quota of the expenditure should be considered:

$$
C F_{t}=\sum_{d} e_{d} \lambda_{d}
$$

where:

- $\quad C F_{t}$ is the expenditure of the $t_{t h}$ year;

- $d$ is the generic Department devoted to welfare according to its own role;

- $\quad e_{d}$ is the expenditure of the $d_{t h}$ Department;

- $\lambda_{d}$ is the percentage of the expenditure that the $d_{t h}$ Department directly or indirectly allocates for land protection. 
A further attribution concerns the area hit by the flood, which can be considered as deserving a quota of the whole annual expenditure. This quota is the "imputation index" that represents the importance of the area from the points of view of some quantitative and qualitative criteria. Then:

$$
C F_{t_{a}}=C F_{t} \mu
$$

where:

- $\quad C F_{t_{a}}$ is the expenditure attributed to the damaged area;

- $\quad \mu$ is the imputation index, i.e., the percentage of $C F_{t}$ attributed to $a$;

- $a$ indicates the damaged area.

The above-mentioned percentage has been calculated as follows:

$$
\mu=\sum_{i} \frac{c_{a i}}{C_{i}} v_{i}
$$

where:

- $\quad c_{a i}$ is the characteristic of the damaged area $a$ to be referred to the $i_{t h}$ criterion $x$;

- $C_{i}$ is the characteristic of the whole regional territory to be referred to the $i_{t h}$ criterion $x$;

- $v_{i}$ is the weight of the $i_{t h}$ criterion $x$.

Finally, once the imputed expenditure is calculated, the social discount rate needs to be calculated in order to take into account the inter-generational solidarity.

The social discount rate $r$ should also take into account the importance of the different areas of the damaged territory, decreasing in cases of valuable areas and vice-versa. According to the mainstream ranges of SDR $r$ can be assumed within a 3.0-5.5\% range and has been calculated for each damaged municipality according to the specific risk level represented by an overall index for each municipality, as displayed in Figure 5; all above indexes converge in a weighted average index.

For each municipality:

$$
r=-0.044 a+0.057
$$

where:

- $\quad a$ is the above-mentioned index, calculated as the average between hydraulic and geomorphological risk indexes:

$$
a=\frac{H\left[n_{\chi}, s_{\chi}\right]+G\left[n_{\varrho}, s_{\varrho}\right]}{2}
$$

where:

- $\quad H$ is the hydraulic risk index;

- $G$ is the geomorphological risk index;

- $n$ is the index of the number of hydraulic or geomorphological risky areas;

- $s$ is the index of the surface of hydraulic or geomorphological risky areas;

- $\quad \chi$ is the relative importance of the class of each hydraulic risky area;

- $\gamma$ is the relative importance of the class of each geomorphological risky area.

The indexes $H$ and $G$ have been calculated as follows:

$$
\begin{aligned}
& H=\left(\sum_{j} n_{h j} \chi_{j}\right) \xi_{n}+\left(\sum_{j} s_{h j} \chi_{j}\right) \xi_{s} \\
& G=\left(\sum_{j} n_{r j} \chi_{j}\right) \xi_{n}+\left(\sum_{j} s_{r j} \chi_{j}\right) \xi_{s}
\end{aligned}
$$

where: 
- $\quad \xi_{n}$ and $\xi_{s}$ represent the relative importance of number of instabilities and surface of the hydraulic and geomorphological risky areas measured as percentage.

\subsection{Methodological Conclusions}

Based on these methodological premises, it is possible to conclude the hypotheses outlined in Section 3.1, starting to distinguish the amount of public expenditure $E$ from its valuation $\bar{e}$ : the former comes from the Regional Government balance sheet; the latter is the public expenditure discounted and imputed:

$$
\bar{e}=V_{e} \mu=\int_{0}^{T} e^{-r t} C F(t) d t \mu
$$

In the same way, it is necessary to distinguish the amount of the reconstruction $\operatorname{cost} C$ from its valuation $\bar{c}$, which is the cost amount related to the event probability:

$$
\bar{c}=C \varepsilon
$$

As a result:

- For equal social discount rate $r$, if as effect of the progressive climatic change probability $\varepsilon$ increases-therefore $\bar{c}$ increases as well-and $\bar{c}>\bar{e}$, then $E$ results as insufficient because the value of safety is underestimated compared to the perception of risk; then, proactive policy can be considered insufficient and it should be increased, enhanced and better finalized;

- For equal social discount rate, if event probability $\varepsilon$ decreases-therefore $\bar{c}$ decreases-and $\bar{c}<\bar{e}$, then $E$ results as redundant because the value of safety is overestimated compared to the perception of risk.

Changing perspective, for equal risk probability $\varepsilon$, it is possible to judge the adequacy of the proactive policy based on the value of the public expenditure that we assumed as representative of the value of safety of territory according to inter/intra-generational solidarity:

- As for inter-generational solidarity, the relation $\overline{\mathrm{e}}<\overline{\mathrm{c}}$ reflects the preference for reactive policies over proactive, therefore requiring a lower consideration for safety than the expense needed for increasing it, and in conclusion a preference for present than future;

- As for intra-generational solidarity, the same relation $\overline{\mathrm{e}}<\overline{\mathrm{c}}$ reflects the underestimation of the coefficient of imputation $\mu$, which is the underestimation of the importance of the affected area compared to the other ones in the regional territory.

\section{Applications and Results}

\subsection{Regional Government Departments' Balance Sheets}

As Sicily is one of the five Special Administrative Italian regions, part of the welfare, such as the proactive land policy, is implemented by the Regional Government, which is articulated in several Departments that directly and indirectly deal with land protection, conservation and enhancement.

The reactive policy, instead, is implemented by the National Civil Protection Department, a special body under the responsibility of the Prime Minister, which deals with the management of emergency. Once the early emergency has been declared, a Special Commissioner is entrusted to manage the funding and the implementation of the restoration works.

The following balance sheet items have been taken into account (Figure 6): "Commitments" of annual expenditure in terms of "Current expenditure" (Title I); "Capital Expenditure" (Title II); "Loans repayments" for operation and investment in "fixed social capital" (Title III).

These types of expenditures have been differently charged according to the degree of involvement of each Department: 
- The Department for Territory and Environment deals entirely with land development; therefore, the related expenditure is entirely charged: in Equation (3) $\lambda_{d}=100 \%$;

- The Department for Agriculture deals with land protection for the part concerning the Forestry Office action: $\lambda_{d}=50 \%$;

- The Presidency of the Regional Government can be considered indirectly involved in land protection, as it coordinates the action of all Departments; therefore, the related expenditure has been calculated according to the ratio between the amount of the annual expenditure by the Department and the total annual regional expenditure, and of course varies yearly: $\lambda_{d 1}=0.44 \%$, $\lambda_{d 2}=1.33 \%, \lambda_{d 3}=2.98 \%$ and so on;

- The same applies to the Department for the Economic and Financial Affairs.

\begin{tabular}{|c|c|c|c|c|c|c|c|}
\hline \multicolumn{2}{|c|}{ DEPARTMENTS AND BUDGET TITLES } & 1 & 2 & 3 & 4 & 5 & \\
\hline Total I & gional Expenditures & $29,635,376$ & $24,875,250$ & $29,635,736$ & $27,390,211$ & $27,701,186$ & \\
\hline & years & 2007 & 2008 & 2009 & 2010 & 2011 & \\
\hline & Current expenditures & 878,443 & 895,431 & 953,038 & 51,854 & 21,760 & \\
\hline & Capital expenditures & 40,937 & 10,730 & 124,623 & 68,173 & 41,315 & \\
\hline PRESIRFNCY & total & 919,380 & 906,161 & $1,077,661$ & 120,027 & 63,075 & \\
\hline & coefficient & $0.44 \%$ & $1.33 \%$ & $2.98 \%$ & $3.19 \%$ & $3.12 \%$ & \\
\hline & total imputed & 4,057 & 12,061 & 32,131 & 3,828 & 1,966 & \\
\hline & Current expenditures & 471 & 441,509 & 542,323 & 143,124 & 118,454 & \\
\hline 2 - DEPARTMENT & Capital expenditures & 134,327 & 91,027 & 570,251 & 705,840 & 728,381 & \\
\hline OF AGRICULTURE & total & 134,798 & 532,536 & $1,112,574$ & 848,964 & 846,835 & \\
\hline AND FORESTRY & coefficient & $50 \%$ & $50 \%$ & $50 \%$ & $50 \%$ & $50 \%$ & \\
\hline & total imputed & 67,399 & 266,268 & 556,287 & 424,482 & 423,418 & \\
\hline & Current expenditures & $4,469,269$ & $3,865,806$ & $3,579,685$ & $3,186,839$ & $3,119,154$ & \\
\hline 4 - DEPARTMENT & Capital expenditures & $7,518,280$ & $8,274,255$ & $9,040,985$ & $7,210,592$ & $9,175,041$ & \\
\hline OF ECONOMIC & Loan rembursement & 338,578 & 236,766 & 207,726 & 838,283 & 250,530 & \\
\hline AND FINANCIAL & total & $12,326,127$ & $12,376,827$ & $12,828,396$ & $11,235,714$ & $12,544,725$ & \\
\hline AFFAIRS & coefficient & $0.44 \%$ & $1.33 \%$ & $2.98 \%$ & $3.19 \%$ & $3.12 \%$ & \\
\hline & total imputed & 54,388 & 164,736 & 382,491 & 358,343 & 390,989 & \\
\hline & Current expenditures & 62,644 & 64,582 & 86,445 & 224661 & 210,966 & \\
\hline 11 - DEPARTMENT & Capital expenditures & 721 & 241 & 240,885 & 224418 & 228,997 & \\
\hline OF TERRITORY & total & 63,365 & 64,823 & 327,330 & 449,079 & 439,963 & \\
\hline AND ENVIONMENT & coefficient & $100 \%$ & $100 \%$ & $100 \%$ & $100 \%$ & $100 \%$ & \\
\hline & total imputed & 63,365 & 64,823 & 327,330 & 449,079 & 439,963 & \\
\hline & "Total expenditure & $13,443,670$ & $\overline{13,880,347}$ & $15,345,961$ & $12,653,784$ & $13,894,598$ & \\
\hline & Imputed expenditure & 189,209 & 507,888 & $1,298,239$ & $1,235,732$ & $1,256,336$ & \\
\hline & Imputation coefficient & $1.54 \%$ & $1.54 \%$ & $1.54 \%$ & $1.54 \%$ & $1.54 \%$ & \\
\hline Basin ann & I imputed expediture & 2,923 & 7,846 & 20,057 & 19,091 & 19,409 & \\
\hline DEPARTMENTS AND & BUDGET TITLES & 6 & 7 & 8 & 9 & 10 & 11 \\
\hline Total I & gional Expenditures & $26,266,860$ & $25,905,185$ & $22,290,621$ & $15,179,646$ & $14,961,125$ & $17,477,131$ \\
\hline & years & 2012 & 2013 & 2014 & 2015 & 2016 & 2017 \\
\hline & Current expenditures & 13,170 & 14,087 & 9884 & 5644 & 5578 & \\
\hline & Capital expenditures & 11,925 & 4,659 & 3702 & 1313 & 1313 & \\
\hline 1 - REGION & total & 25,095 & 18,746 & 13,586 & 6,957 & 6,891 & 9,145 \\
\hline & coefficient & $2.55 \%$ & $2.73 \%$ & $1.09 \%$ & $0.91 \%$ & $0.92 \%$ & \\
\hline & total imputed & 639 & 513 & 148 & 64 & 63 & 92 \\
\hline & Current expenditures & 103,891 & 225,335 & 177614 & 16014 & 15939 & \\
\hline 2 - DEPARTMENT & Capital expenditures & 616,425 & 415,142 & 16618 & 9930 & 8365 & \\
\hline OF AGRICU & total & 720,316 & 640,477 & 194,232 & 25,944 & 24,304 & 81,493 \\
\hline AND FORESTRY & coefficient & $50 \%$ & $50 \%$ & $50 \%$ & $50 \%$ & $50 \%$ & \\
\hline & total imputed & 360,158 & 320,239 & 97,116 & 12,972 & 12,152 & 40,747 \\
\hline & Current expenditures & $3,258,683$ & $4,139,313$ & 2634533 & 2047248 & 2651547 & \\
\hline 4 - DEPARTMENT & Capital expenditures & $9,783,419$ & $8,605,564$ & 7138119 & 809706 & 275111 & \\
\hline OF ECONOMIC & Loan rembursement & 225,298 & 259,432 & 286493 & 273331 & 254,882 & \\
\hline AND FINANCIAL & total & $13,267,400$ & $13,004,309$ & $10,059,145$ & $3,130,285$ & $3,181,540$ & $5,456,990$ \\
\hline AFFAIRS & coefficient & $2.55 \%$ & $2.73 \%$ & $1.09 \%$ & $0.91 \%$ & $0.92 \%$ & \\
\hline & total imputed & 337,893 & 355,591 & 109,428 & 28,608 & 29,315 & 55,784 \\
\hline & Current expenditures & 193,234 & 193,991 & 145242 & 125712 & 125656 & \\
\hline 11 - DEPARTMENT & Capital expenditures & 115,570 & 194,124 & 129 & 45 & 45 & \\
\hline & total & 308,804 & 388,115 & 145,371 & 125,757 & 125,701 & 218,750 \\
\hline AND ENVIONMENT & coefficient & $100 \%$ & $100 \%$ & $100 \%$ & $100 \%$ & $100 \%$ & \\
\hline & total imputed & 308,804 & 388,115 & 145,371 & 125,757 & 125,701 & \\
\hline & Total expenditure & $\overline{14,321,615}$ & $\overline{14,051,647}$ & $\overline{10,412,334}$ & $3,288,943$ & $3,3,338,436$ & $\overline{9,082,595}$ \\
\hline & Imputed expenditure & $1,007,494$ & $1,064,457$ & 352,063 & 167,401 & 167,231 & 551,729 \\
\hline & Imputation coefficient & $1.54 \%$ & $1.54 \%$ & $1.54 \%$ & $1.54 \%$ & $1.54 \%$ & $1.54 \%$ \\
\hline Basin ann & I imputed expediture & 15,565 & 16,445 & 5,439 & 2,586 & 2,584 & 8,524 \\
\hline
\end{tabular}

Figure 6. Sicilian Regional Government Balance Sheets 2007-2016 and imputation coefficient. Year 2017 reports the average amounts of the previous ten years (000EUR).

\subsection{Imputed Expenditures}

Overall, the report shows a progressive reduction of the public expenditures for the proactive policies. 
The last line of Figure 6 reports the coefficients for the imputation of the total expense to the relative value of the damaged river basin $n$. 102 out of the total of 102 river basins located in the entire regional territory, as identified and delimited by the Hydrogeological Arrangement Plan. Each river basin has been characterized by means of quantitative and qualitative criteria based on the data in the Regional Landscape Territorial Plan (RLTP) Guidelines.

The expenditures imputed to the river basin $\mathrm{n}$. 102 were calculated with regard to several characteristics $c_{a i}$ in formula (5).

The quantitative or dimensional characteristics are:

- The ratio between the surface of the river basin and the total surface of Sicily; the river basin n. 102 surface is about 4136 ha, corresponding to $0.69 \%$ of the regional territory.

- The ratio between the length of the river network of the basin and the overall length of all Sicilian river basins; the total length of the entire river system of the river basin n. 102 is approximately $71.2 \mathrm{~km}$, which corresponds to $0.55 \%$ of the entire regional hydraulic network (Figure 7).
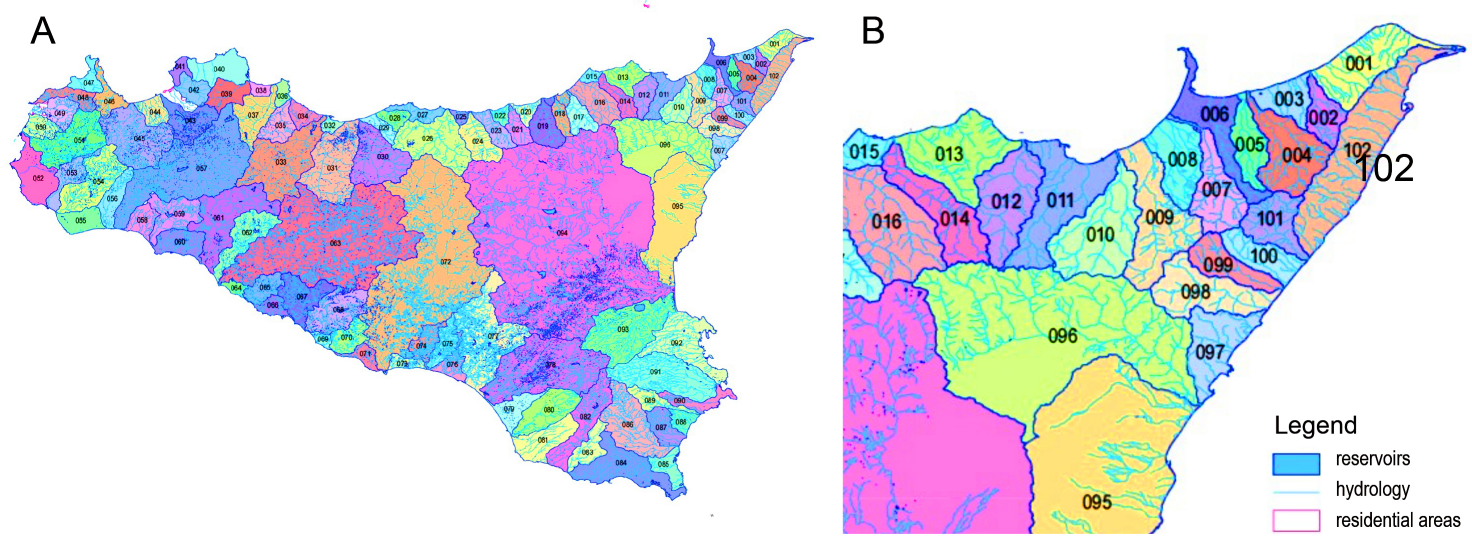

Figure 7. Hydraulic Regional framework (A) and detail of the Province of Messina displaying the Fiumedinisi river basin n. 102 (B).

The average imputation ratio based on the river basin extension is $0.65 \%$. The qualitative characteristics are defined by combining land uses and ecological and natural value, based on the spatial analysis functions of the Geographical Information System (GIS); the different uses of the soil have been classified into a dimensionless numerical scale, and depend on rarity, degree of naturalness, cultural value, landscape and environmental value.

- Anthropological importance is referred to the land uses, including the capital invested in stable assets [64-66]; each of them scored as reported in the above-mentioned RLTP Guidelines, taking into account the territorial value [67]. The scores measure the importance of each land use in terms of economic, functional, vegetation and agricultural performance; the imputation index of the River Basin n. 102 is $0.91 \%$, lower than the median of the entire Sicilian territory $(0.98 \%)$ (Figures 8 and 9).

- Ecological, eco-systemic and naturalistic importance $[68,69]$ is referred to the surface of the river basin occupied by protected areas (Sites of Community Importance-SCI—and Zones of Special Protection-ZSP); the river basin comprises the protected areas ITA030008, ITA030010 and ITA030011 (3768 ha) corresponding to $21.6 \%$ of its total surface, above the median of the river basins of the entire regional territory (Figure 10). 


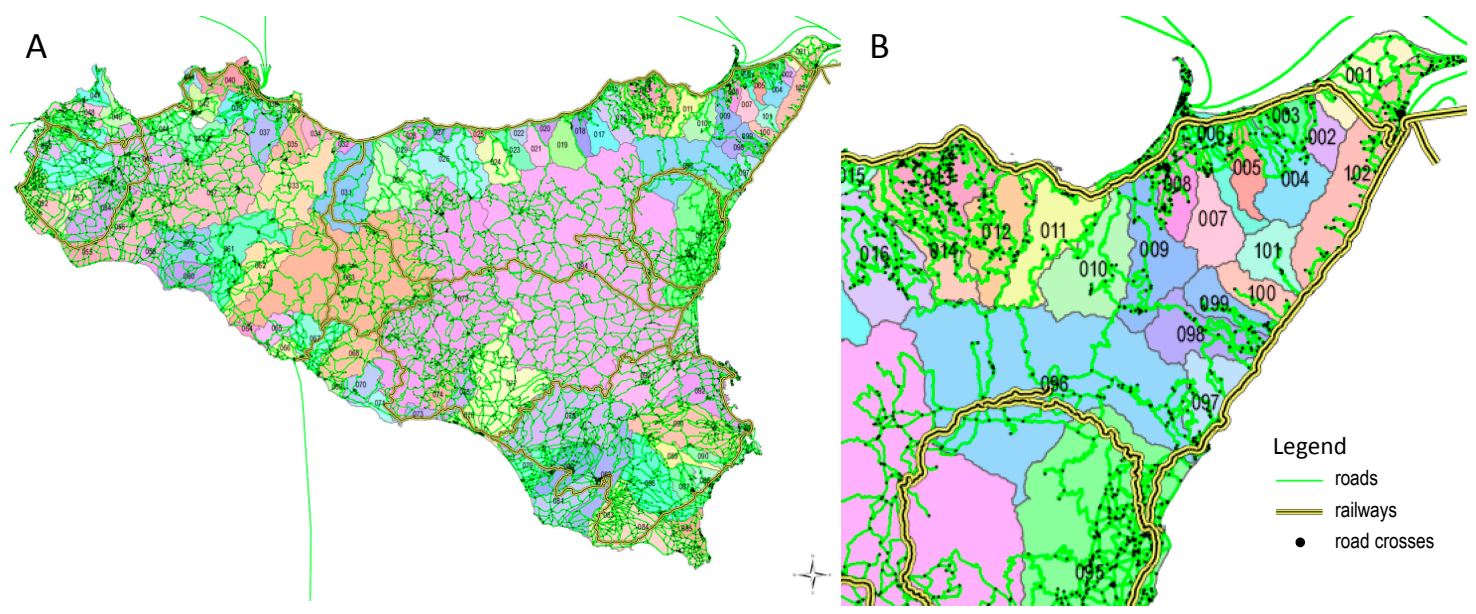

Figure 8. Anthropological arrangement in Sicily (A) and in the Fiumedinisi river basin area (B).

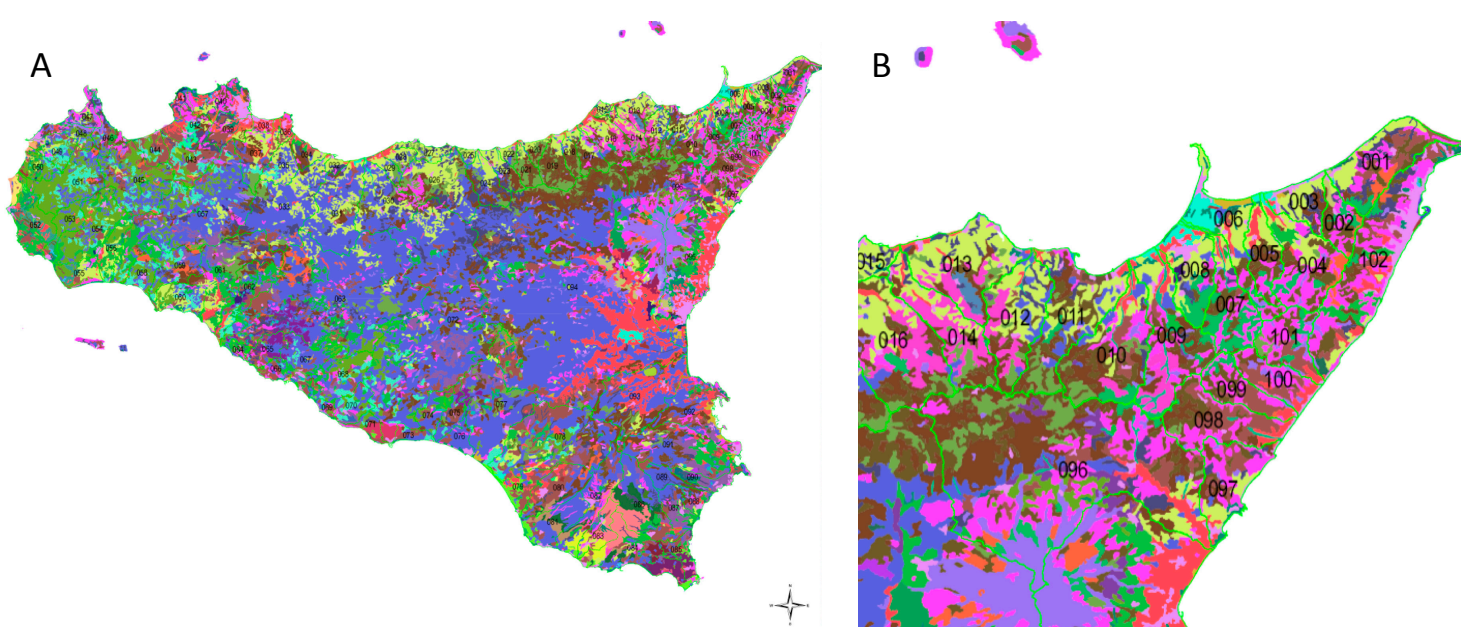

Figure 9. Land uses in Sicily (A) and in the Fiumedinisi river basin area (B).

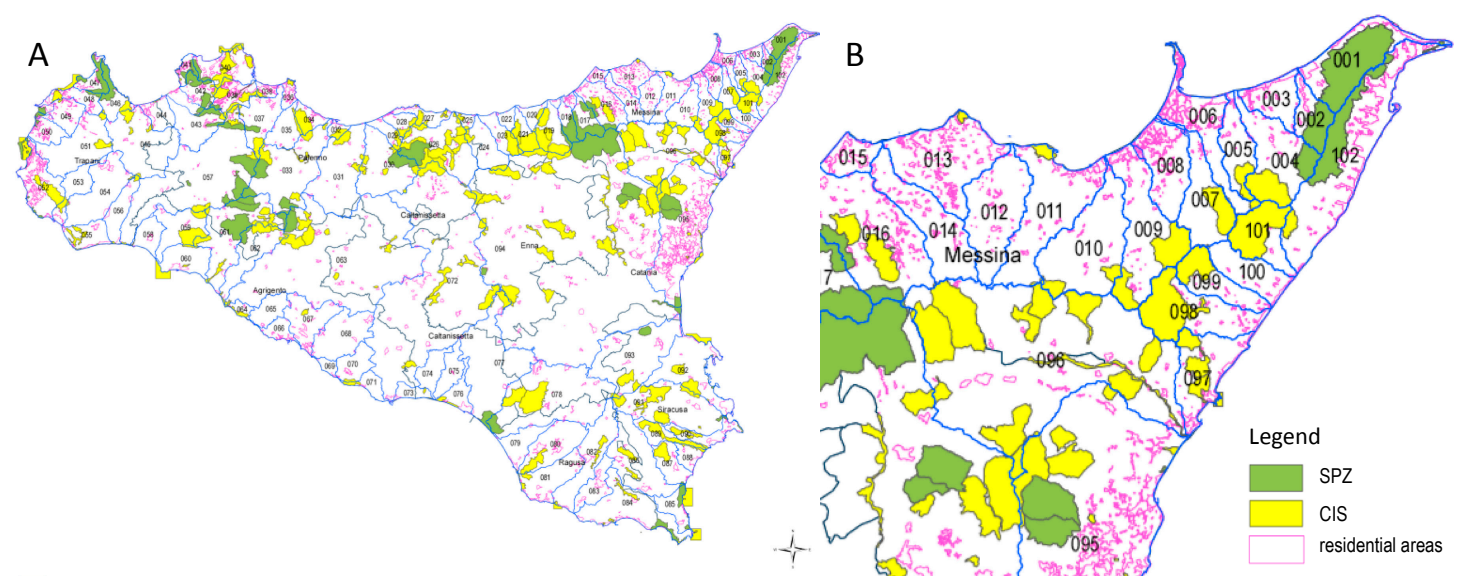

Figure 10. Sites of Community Importance and Special Protection Zones in Sicily (A) and in the Fiumedinisi river basin area $(\mathbf{B})$.

- Overall hydraulic-geomorphological risk is given by the ratio between the risk coefficient of each basin and the sum of the risk coefficients of all basins. The risk coefficient of each basin in calculated as ratio between the surfaces of the total risky area and the total area of the river basin. 
The imputation ratio is $1.54 \%$ (Figure 11).

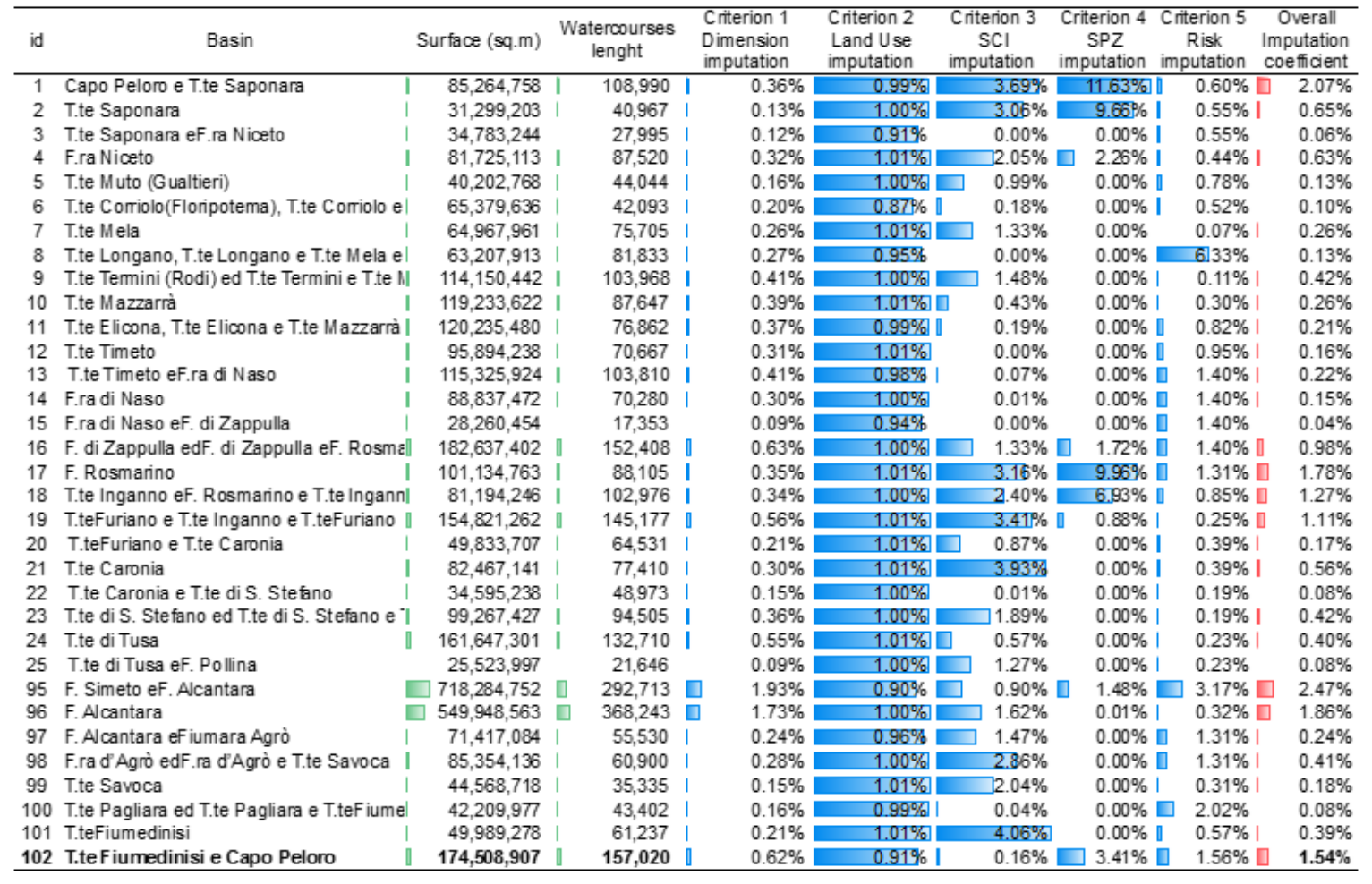

Figure 11. Synthesis of the coefficient of imputation calculated for the river basins in the Messina Province according to the four criteria (river basins 26-94 omitted).

\subsection{Overall Economic Valuation}

The partial results reported so far can finally be used to calculate the monetary measurement of the value of the proactive policy to be compared to the total reconstruction cost. A Discounted Cash Flow Analysis was carried out by using the imputed expenses from the Regional Government balance sheets, over a conventionally assumed period of 20 years, from 2007 until 2026. The cash flow includes the real expenditures up until 2016 and the average supposed amounts from 2017. Furthermore, some scenarios were outlined assuming different hypotheses about the social discount rate (SDR), therefore assuming different approaches to inter-generational solidarity. The calculation has been carried out in the following steps:

1. The comparison of the different areas involved has been carried out by charging different quotas of the overall imputed amount to the five municipalities, proportionally to the risk level of each of the municipalities involved. According to the following percentages: Messina $71.0 \%$, Scaletta Zanclea 11.1\%, Itala 7.3\%, Alì Terme 5.2\%, Alì 5.4\%.

2. Within a range from $3.00 \%$ to $5.50 \%$ (as recommended by the European Cost-Benefit Analysis Guidelines) a different SDR has been attributed to each of the five municipalities in inverse proportion to the risk level of the above-mentioned areas: Messina 3.00\%, Scaletta Zanclea $4.8 \%$, Itala $5.42 \%$, Alì Terme $5.50 \%$, Alì $5.49 \%$. The overall SDR, 3.69\%, has been calculated as average SDR weighted taking into account the number of instabilities as well.

3. The value of land protection in each municipality has been calculated by discounting the related cash flows.

Figure 12 displays the comparison between the imputed 0-discount and the discounted cash flows for the five municipalities and the overall area, each of them according to the related SDR. 

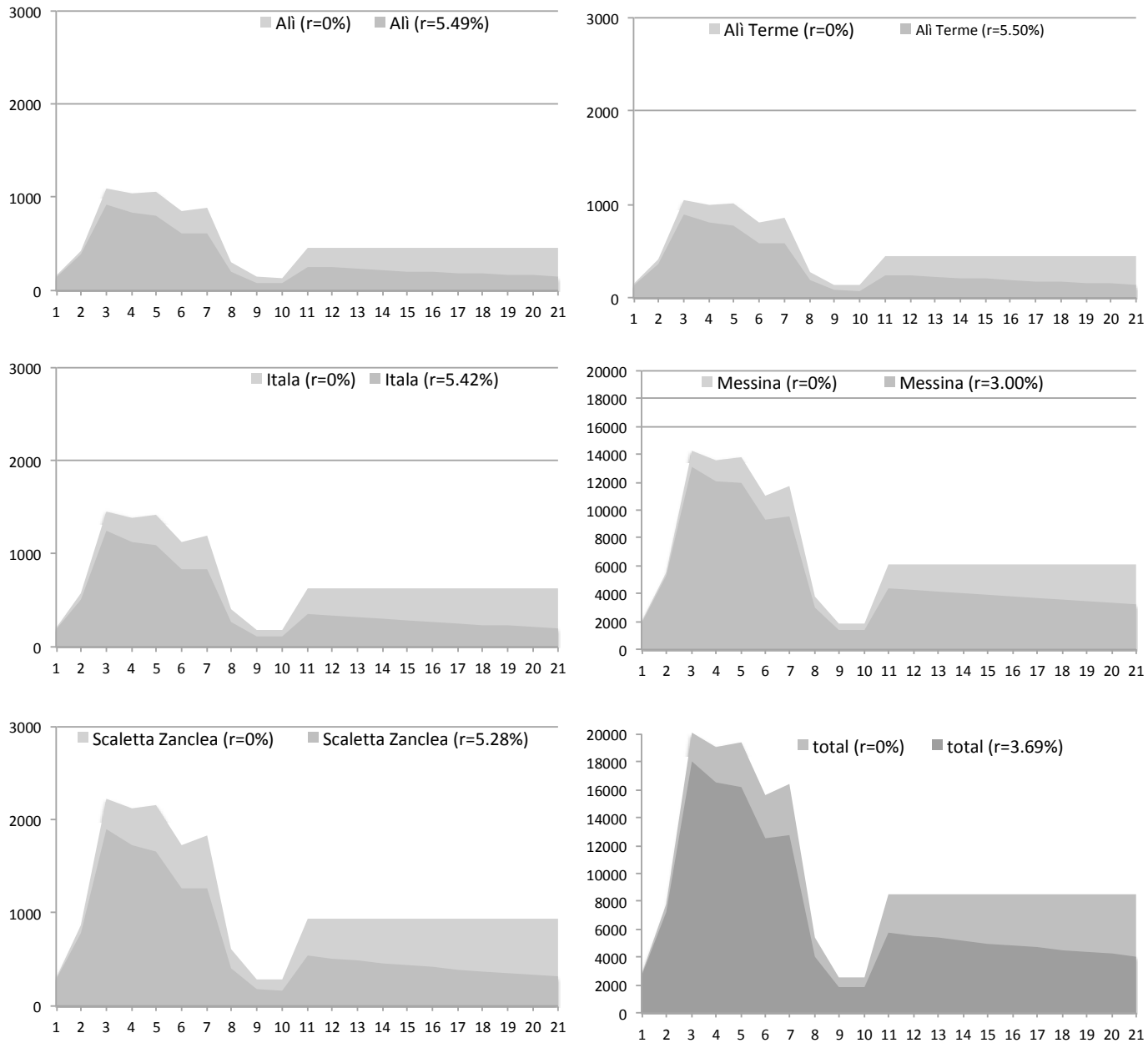

Figure 12. Comparison of the imputed 0-discount and discounted cash flows for the five municipalities and the overall area, each of them according to the related SDR $(r)$ (y-axis: 000EUR).

4. The different scenarios about the type of discounting have been carried out by comparing four of the many possibilities outlined in Section 3.3, and in particular, "0 discount", "decreasing by step discount", "decreasing discount", "constant discount" (Figure 13).

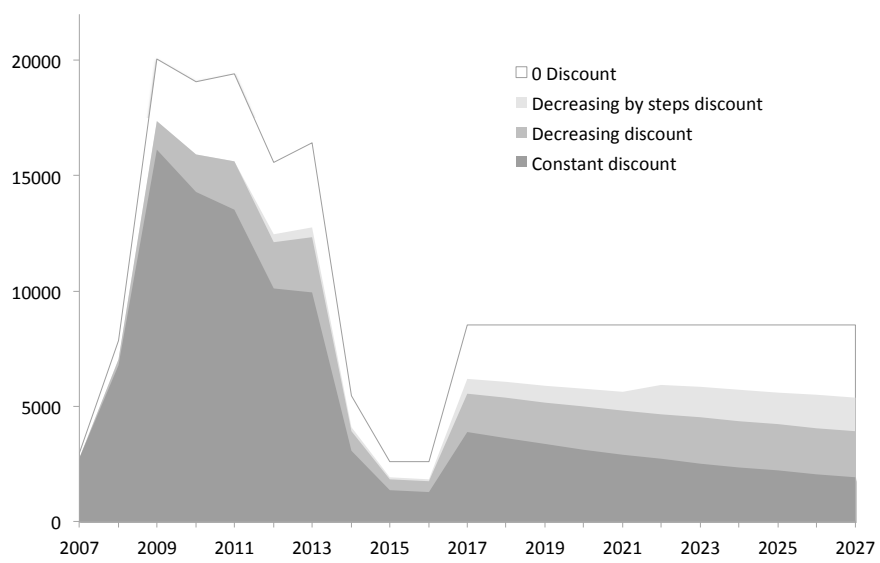

Figure 13. Scenarios of the Net Present Values (the white and grey surfaces) of the imputed expenditure cash flow according to different hypotheses of inter-generational solidarity (y-axis: 000EUR). 


\section{Discussion}

The economic valuation of the damage involves the way discount rate is assumed based on expectation of greater awareness and responsibility about the hazard and the exposure of territories, and especially about the speed at which climate change modifies the rainfall regimes.

The implementation of four inter-temporal solidarity hypotheses, according to formula (10), shows that: the value of the current discounted expenditure (formula (10)) is equal to $€ 109.7$ million; if the SDR has a hyperbolic decrease, the value is $€ 142.2 .0$ million; if the SDR has a hyperbolic decrease by steps (every five years) the value is $€ 155.2$ million; whereas the 0 -discounted value is $€ 205.7$ million.

The outlined range of values needs to be compared to the recovery cost, that is $€ 320$ million, and in particular to the value of such cost, i.e., the cost related to the event probability (formula (11)).

As reported in Figure 4 (Section 2.2), the probability of flood remains high, and since 2009 three similar precipitation events have occurred (October 2009, November 2012 and January 2017), although none of them caused similar damages.

Then, trying to judge the adequacy of proactive policy by retracing the assessment approach outlined in Section 3.5, we compare the value of territory safety $\bar{e}$ to the value of recovery cost $\bar{c}$ based on the four SDR inter-generational solidarity scenarios outlined, and on four event probability rates, as reported in Table 1 displaying the results corresponding to each of the 16 combinations at the weighted average rate of $3.69 \%$ (Section 4.3 ).

Table 1. Differences between the value of territory safety $\overline{\mathrm{e}}$ and the recovery cost value $\bar{c}$ under four discounting scenarios and four event probability rates (000,000EUR).

\begin{tabular}{ccccc}
\hline \multirow{2}{*}{ Inter-Generational Solidarity Scenarios } & \multicolumn{4}{c}{ Event Probability Rate } \\
\cline { 2 - 5 } & $\mathbf{0 \%}$ & $\mathbf{3 3 \%}$ & $\mathbf{6 7 \%}$ & $\mathbf{1 0 0} \%$ \\
\hline 0 Discount & 206 & 99 & -8 & -114 \\
Decreasing by steps discount & 155 & 49 & -58 & -165 \\
Decreasing discount & 142 & 36 & -71 & -178 \\
Constant discount & 110 & 3 & -104 & -210 \\
\hline
\end{tabular}

These findings are also displayed in Figure 14 where, supposing SDR ranging from 0\% to 8\%, the trade-off between risk and solidarity is outlined. These trade-off functions are displayed by the central curves (in red) in the lower diagrams, each point of which represents the combinations of SDR and risk rate by which is $\bar{e}=\bar{c}$.

The curve is almost in the same position in the two decreasing discount approaches (A and B), both supposing a higher level of inter-generational solidarity, whereas it is lower in the constant discount approach (C) supposing a lower level of inter-generational solidarity; supposed-0 discounting is not relevant in this experiment. The diagrams in the higher part of Figure 14 show that the surface is more sloping in the scenario with a low level of inter-generational solidarity.

In conclusion, some considerations can be addressed about 1 . inter-generational and 2. intra-generational solidarity.

1. As for inter-generational solidarity:

- In the first scenario-0 discount-equilibrium $\bar{e}=\bar{c}$ is at a $64 \%$ risk rate;

- In the second scenario, supposing a SDR decreasing by step starting from 3.69\%, equilibrium $\bar{e}=\bar{c}$ is at $49 \%$ risk rate;

- In the third scenario, supposing a SDR hyperbolically decreasing starting from $3.69 \%$ as well, equilibrium $\bar{e}=\bar{c}$ is at $43 \%$ risk rate;

- In the fourth scenario, supposing a constant SDR of 3.69\%, equilibrium $\bar{e}=\bar{c}$ is at $35 \%$ risk rate. 
A
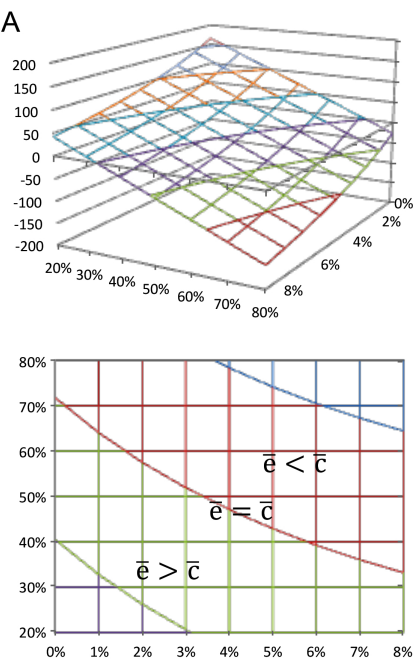

B
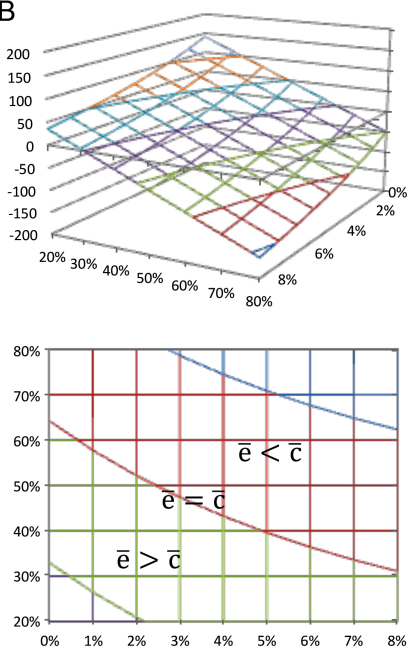

C
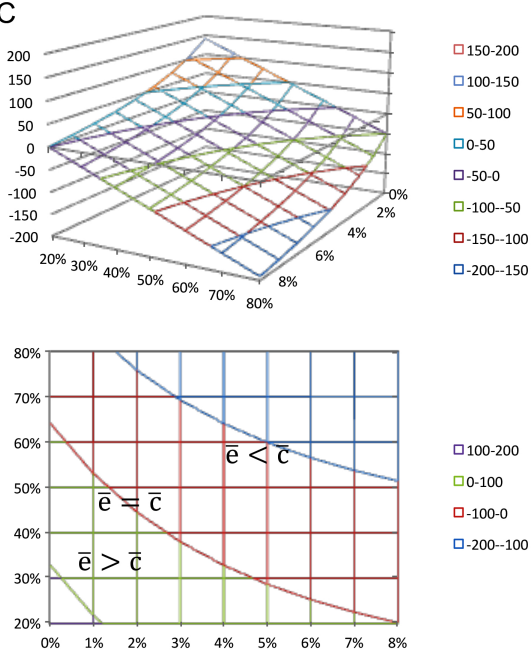

50-200

$-100-50$

$\square 100-200$

$\square 0-100$

$\square-100-0$

-200-100

Figure 14. Trade-off between social discount rate (SDR) and risk level for three discounting approaches: (A) Decreasing by steps discounting; (B) Decreasing discounting; (C) Constant discounting (legend: 000,000EUR).

The second and third scenarios reflect a substantial balance between the value of territory safety and the value of recovery cost, that is, the amount of the public expenditures discounted and imputed is almost equal to the probable recovery cost, at a 50\% risk rate. Such a rate is relevant due to both the persisting instabilities all over the river basin, and the long period along which the effects of catastrophe have extended.

Due to the persisting hydraulic and geomorphologic risk status in the area we can conclude that public expenditures are adequate, but not effective; that is the operating cost of the involved Departments exceeds the normal rate, so that the residual intervention budgets are poor. According to these scenarios, public expense does $\mathrm{n}$ have to be increased, but rather it should be made more effective.

It should be considered that the above-mentioned scenarios are not consistent with the European CBA Guidelines, which instead suppose the continue discount approach, here performed in the fourth scenario. In such case, at $50 \%$ risk rate $\bar{e}<\bar{c}-$ specifically $\bar{e}-\bar{c}=-49,000,000$.

Interpreting this finding according to the imputed preference approach, it can be concluded that preference for present prevails and reactive policy is preferred to a proactive one, so that public expenditure needs to be increased and made more effective as well.

Furthermore, this finding could suggest how much and in which direction public expense should be allocated; the latter concern involves the intra-generational solidarity issue.

2. As for intra-generational solidarity:

- As mentioned in Section 3.4, the relative importance of each river basin, measured by imputation coefficient $\mu$, formula (4), can be assumed to drive the public expense to the best allocation in view of the territory vulnerability reduction; such coefficient has been calculated according to the above-mentioned five criteria (Section 4.2) to which specific weights have been attributed;

- As mentioned in Section 3.5, the condition $\bar{e}<\bar{c}$ means that, with a fixed budget, the critical areas, such as the studied one, need to be more equally imputed, by modifying the weights of the criteria, in particular, in favor of risk and land use, reaching up to the equilibrium condition $\bar{e}=\bar{c}$; as a consequence the given budget will be differently allocated according to the new arrangement of the imputation indexes attributed to each of the Sicilian river basins;

- If, $\bar{e}<\bar{c}$ yet, the total amount of the public expense need to be increased. 


\section{Conclusions}

The set of tools we used and combined here is the information basis supporting decision makers committed in implementing proactive policies in the ground of soil protection from flood.

The proposed model is arranged in order to identify the recovery cost as the benchmark for the value of territory safety, assuming that the former is related to reactive interventions for emergency, and the latter to proactive measures aimed at reducing the risk of heavy consequences and irreversible damages.

Due to the heterogeneity of the risk factors featuring the Sicilian territory-hazard, vulnerability and exposure-public expenditures for territory protection need to be appropriately dimensioned and allocated.

As for dimensioning public expense, the amount needs to be able to prevent or reduce damages, as for allocation, public expense needs to fit the characteristics of the different land contexts.

This study suggests how to perform the above-mentioned comparisons, typically according to the imputed preferences approach, by assuming the current public expense for prevention as the basis for the monetary measurement of the value of safety from flood.

Referring to the real case of the flood that occurred in 2009 in the Messina province, whose recovery cost is known, we assumed such cost as a benchmark for the valuation of the public expense adequacy.

In order to calculate which part of the public expense that occurred corresponds to the value of the recovery cost, we carried out:

- An imputation model identifying the intra-generational solidarity degree, which the allocation of the expense over regional territory is based on;

- A discounting model identifying the inter-generational solidarity degree, which the allocation of the budget between protection and emergency is based on.

The imputation model is based on a spatial and qualitative GIS calculation pattern providing the sorting of the different river basins according to which the overall budget should be allocated.

The discounting model is aimed at calculating the Social Discounting Rate to be applied to the public expense stream over a defined time span, outlining four relevant scenarios, each one performing a different inter-temporal solidarity degree.

At last, the findings revealed the profile of public expense from the perspective of the intra and inter-generational solidarity degree.

The findings confirmed that, for equal risk rate, the current expense for land protection can be considered adequate and well imputed just for the scenarios that envisage a broader time perspective (Section 5). Otherwise, the usual discounting scenario, which is characterized by a prevailing preference for present than future, shows how much a reactive approach is preferred to the proactive one.

Such a premise can be assumed as a methodological basis for dimensioning and allocating public expense so as to avoid or reduce as much as possible irreversible transformations such as the ones that occurred in the studied area.

Supplementary Materials: The following are available online at: http:/ / osservatorioacque.it/: Figures S2 and S3; http:/ / pti.regione.sicilia.it/portal/page/portal/PIR_PORTALE: Figure S6.

Author Contributions: Maria Rosa Trovato and Salvatore Giuffrida equally conceived this study, analyzed the data, performed the calculations and wrote the paper.

Conflicts of Interest: The authors declare no conflict of interest.

\section{References}

1. Giuffrida, S.; Ferluga, G.; Trovato, M.R. Flood Risk and Land Resilience: A Socio-Systemic Approach to valuation. In Proceedings of the 19th IPSAPA/ISPALEM International Scientific Conference: The Turning Point of the Landscape-Cultural Mosaic: Renaissance Revelation Resilience; Reggio Calabria, Italy, 6-7 July 2016; Piccinini, L.C., Ed.; 2016; pp. 29-41. 
2. Tremmel, J.C. (Ed.) Handbook of Intergenerational Justice; Edward Elgar: Cheltenham, UK, 2006.

3. Torjman, S. What Is Policy? Caledon Institute of Social Policy: Ottawa, ON, Canada, 2005; ISBN 1-55382-142-4.

4. Hauser, J.R.; Rao, V.R. Conjoint Analysis, Related Modeling, and Applications. In Advances in Marketing Research: Progress and Prospects; A Tribute to Paul Green's Contributions to Marketing Research Methodology; MIT Sloan School of Management, Massachusetts Institute of Technology: Cambridge, MA, USA, 2002.

5. Signorello, G.; Cucuzza, G.; De Salvo, M. Valutazione contingente del paesaggio agrario della Costa Viola. In Gli Interventi Paesaggistico-Ambientali nelle Politiche Regionali di Sviluppo Rurale; Marangon, F., Ed.; FrancoAngeli: Milano, Italy, 2006.

6. Huber, J. What We Have Learned from 20 Years of Conjoint Research; Fuqua School of Business, Duke University: Durham, NC, USA, 1997.

7. Cimnaghi, E.; Roscelli, R. Dalla valutazione ex-post del danno ambientale alla convenienza econmica delle politiche di prevenzione: Una proposta metodologica per le aree protette. Valori e Valutazioni 2012, 9, 61-90.

8. Pimentel, D.; Wilson, C.; McCullum, C.; Huang, R.; Dwen, P.; Flack, J.; Tran, Q.; Saltman, T.; Cliff, B. Economic and Environmental benefits of Biodiversity. Bioscience 1997, 47, 747-757. [CrossRef]

9. Kremen, C.; Niles, J.O.; Daltonm, G.; Dailyg, C.; Ehrlich, R.; Fay, J.P.; Grewal, D.; Guillery, R.P. Economic Incentives for Rain Forest Conservation Across Scales. Science 2000, 288, 1828-1832. [CrossRef] [PubMed]

10. Merlo, M.E.; Croitoru, L. Valuating Mediterranean Forests-Towards Total Economic Value; CABI Publishing: Wallingford, UK, 2005.

11. Bateman, I.J.; Turner, R.K. Valuation of the environment methods and techniques: The contingent valuation method. In Sustainable Environmental Economics and MANAGEMEnt: Principles and Practice; Turner, R.K., Ed.; Belhaven Press: London, UK, 1993.

12. Freeman, A.M., III. The Measurement of Environmental and Resource Values: Theory and Methods; Resources for the Future: Washington, DC, USA, 1993.

13. Gios, G.; Notaro, S. La Valutazione Economica dei Beni Ambientali: Introduzione al Metodo della Valutazione Contingente; Cedam: Padova, Italy, 2001.

14. Hansoon, K.; Danielson, M.; Ekenberg, L. A framework for evaluation of flood management strategies. J. Environ. Manag. 2008, 86, 465-480. [CrossRef] [PubMed]

15. Kramer, R.A.; Richter, D.D.; Subhrendu, P.E.; Sharma, N.P. Ecological and economic Analysis of watershed protection in eastern Madagascar. J. Environ. Manag. 1995, 49, 277-295. [CrossRef]

16. Pearce, D.W.; Turner, R.K. Economics of Natural Resources and the Environmental; Harvest Wheatseaf: New York, NY, USA, 1990.

17. Naselli, F.; Trovato, M.R.; Castello, G. An evaluation model for the actions in supporting of the environmental and landscaping rehabilitation of the Pasquasia's site mining (EN). In ICCSA 2014, LNCS 8581; Murgante, B., Ed.; Springer International Publishing: Cham, Switzerland, 2014; Part III; pp. 26-41.

18. Drago, A. Climatological Atlas of Sicily. Riv. Ital. Agrometeorol. 2005, 2, 67-83.

19. Osservatorio delle acque. Available online: http:/ / osservatorioacque.it/ (accessed on 22 April 2018).

20. Assessorato Regionale dell'Energia e dei Servizi di Pubblica Utilità. Rapporto Annuale di Monitoraggio Regionale della Siccità e della Disponibilità Idrica degli Invasi; Assessorato Regionale dell'Energia e dei Servizi di Pubblica Utilità: Palermo, Italy, 2017.

21. Regione Siciliana, Assessorato Territorio e Ambiente, Piano Stralcio di Bacino per l'Assetto Idrogeologico (P.A.I.) 2006. Available online: http:/ / www.sitr.regione.sicilia.it/pai/ (accessed on 12 December 2017).

22. Holbrook, M.B.; Moore, W.L.; Dodgen, G.N.; Havlena, W.J. Nonisomorphism, Shadow Features and Imputed Preferences. Market. Sci. 1985, 4, 215-233. [CrossRef]

23. Mercier, H.; Sperber, D. Why Do Human Reason? Arguments for an Argumentative Theory. Behav. Brain Sci. 2011, 34, 57-74. [CrossRef] [PubMed]

24. Labinaz, P. La Razionalità; Carocci: Roma, Italy, 2013.

25. Arrow, K.; Bolin, B.; Costanza, R.; Dasgupta, P.; Folke, C.; Holling, C.S.; Jansson, B.O.; Levin, S.; Maler, K.G.; Perrings, C.; et al. Economic Growth, Carrying Capacity, and the Environment. Ecol. Econ. 1995, 15, 91-95. [CrossRef]

26. Bresso, M. Per Un'economia Ecologica; NIS: Roma, Italy, 1993.

27. Giuffrida, S.; Trovato, M.R.; Falzone, M. The information value for territorial and economic sustainability in the enhancement of the water management process. In ICCSA 2017, LNCS 10406; Borruso, G., Ed.; Springer: London, UK, 2017; Volume III, pp. 575-590. 
28. Giuffrida, S.; Casamassima, G.; Trovato, M.R. Le norme EMAS-ISO nella valutazione della qualità del servizio idrico integrato. In AESTIMUM; Firenze University Press: Firenze, Italy, 2017; Volume 70, pp. 109-134.

29. Ramsey, F.P. A mathematical theory of saving. Econ. J. 1928, 38, 543-559. [CrossRef]

30. Pearce, D.W.; Ulph, D. A Social Discount Rate for the United Kingdom. In Environmental Economics: Essays in Ecological Economics and Sustainable Development; Pearce, D.W., Ed.; Edward Elgar: Cheltenham, UK, 1999; pp. 268-285.

31. Oxera, A. A Social Time Preference Rate for Use in Long-Term Discounting; The Office of the Deputy Prime Minister, Department for transport and Department for the Environment, Food and Rural Affairs: London, UK, 2002.

32. Pearce, D.W.; Groom, B.; Hepburn, C.; Koundoury, P. Valuing the future. Recent advances in social discounting. Word Econ. 2003, 4, 121-141. [CrossRef]

33. Stern, N.; Peters, S.; Bakhshi, V.; Bowen, A.; Cameron, C.; Catovsky, S.; Crane, D.; Cruickshank, S.; Dietz, S.; Edmonson, N.; et al. Stern Review: The Economic of Climate Change; HM Treasury: London, UK, 2006.

34. Page, T. Conservation and Economic Efficiency: An Approach to Materials Policy. In Resources for the Future; John Hopkins University Press: Baltimore, MD, USA, 1997.

35. Page, T. On the Problem of Achieving Efficiency and Equity, Intergenerationally. Land Econ. 1997, 73, 580-597. [CrossRef]

36. Broome, J. Weighting Goods: Equality Uncertainty and Time; Blackwell: Oxford, UK, 1991.

37. O'Neil, J. Ecology. Policy and Politics: Human Wellbeing and the Natural World; Routledge: London, UK, 1993.

38. Van den Bergh, J.C.; Hofkes, M.W. Theory and Implementation of Economic Model for Sustainable Development; Kluver: Dordrecht, The Netherlands, 1998.

39. Jones, G.E.; Davies, B.; Hussian, S. Ecological Economics; Blackwell Science: Oxford, UK, 2000.

40. Fisher, A.C.; Krutilla, J.V. Resources Conservation, Environmental Preservation and the Rate of Discount. Q. J. Econ. 1975, 89, 358-370. [CrossRef]

41. Slow, R.M. The Economics of Resources or the Resources of Economics. Am. Econ. Rev. 1974, 64, 1-15.

42. Rochet, J.C.; Gollier, C. Discounting an Uncertain Future; Mimeo, Université de Touloise: Touloise, France, 1998.

43. Weitzaman, M.L. On the Environmental Discount Rate. J. Environ. Econ. Manag. 1994, 26, 200-209. [CrossRef]

44. Weitzaman, M.L. Why the far distance future should be discounted at its lowest possible rate. J. Environ. Econ. Manag. 1998, 36, 201-208. [CrossRef]

45. Weitzaman, M.L. Gamma discounting. Am. Econ. Rev. 2001, 91, 260-271. [CrossRef]

46. Weitzaman, M.L.; Martin, L. Review of the "Stern Review on the Economics of Climate Change". J. Econ. Lit. 2007, 45, 703-724. [CrossRef]

47. Weitzaman, M.L. Risk-Adjusted Gamma Discounting. J. Environ. Econ. Manag. 2010, 60, 1-13. [CrossRef]

48. Gollier, C. Time Horizon and Discount Rate; Mimeo, Université de Touloise: Touloise, France, 1999.

49. Gollier, C. Discounting an uncertain future. J. Public Econ. 2002, 85, 149-166. [CrossRef]

50. Gollier, C. Discounting with fat-tailed economic growth. J. Risk Uncertain. 2008, 37, 171-186. [CrossRef]

51. Gollier, C. Ecological Discounting. J. Econ. Theory 2010, 145, 812-829. [CrossRef]

52. Gollier, C. Discounting and Risk Adjusting Non-Marginal Investment Project. Eur. Rev. Agric. Econ. 2011, 38, 325-334. [CrossRef]

53. Gollier, C. On the underestimation of the precautionary effect in discounting. Geneva Risk Insur. Rev. 2011, 36, 95-111. [CrossRef]

54. Newell, R.G.; Pizer, W.A. Discounting the distant future: How much do uncertain rates increase valuations? J. Environ. Econ. Manag. 2003, 46, 52-71. [CrossRef]

55. Alamansa, C.; Calatrava, J. Reconciling Sustainability in Cost Benefit Analysis: A methodological Proposal. Ecol. Econ. 2007, 60, 712-725. [CrossRef]

56. Hepburn, C.; Groom, B. Gamma Discounting and Expected net Future values. J. Environ. Econ. Manag. 2007, 53, 99-109. [CrossRef]

57. Kogel, T. On the Relation between Dual-Rate Discounting and sustainability. Economics 2009, 28, $2009-2027$.

58. Kula, E.; Evans, D. Dual Discounting in Cost-benefit Analysis for Environmental Impacts. Environ. Impact Assess. Rev. 2011, 31, 180-186. [CrossRef]

59. Alamansa, C.; Martinez Paz, J.M. Intergenerational Equity and Dual Discounting. Environ. Dev. Econ. 2011, 16, 685-707. [CrossRef]

60. Gollier, C. The Economics of Risk and Time; MIT Press: Cambridge, MA, USA; London, UK, 2004. 
61. European Union. Guide to Cost-Benefit Analysis of Investment Projects; European Union: Brussels, Belgium, 2008.

62. HM Treasury. Intergenerational Wealth Transfer and Social discounting: Supplementary Green Book Guidance; Lowe, J., Ed.; HM Treasury: London, UK, 2008.

63. HM Treasury. The Green Book, Appraisal and Evaluation in Central Government; HM Treasury: London, UK, 2003.

64. Giuffrida, S.; Ventura, V.; Trovato, M.R.; Napoli, G. Axiology of the historical city and the cap rate. The case of the old town of Ragusa Superiore. Valori e Valutazioni 2017, 18, 41-55.

65. Napoli, G.; Giuffrida, S.; Trovato, M.R.; Valenti, A. Cap Rate as the Interpretative Variable of the Urban Real Estate Capital Asset: A Comparison of Different Sub-Market Definitions in Palermo, Italy. Buildings 2017, 7, 80. [CrossRef]

66. Nesticò, A.; Galante, M. An estimate model for the equalisation of real estate tax: A case study. Int. J. Bus. Intell. Data Min. 2015, 10, 19-32. [CrossRef]

67. Giuffrida, S.; Trovato, M.R. A Semiotic Approach to the Landscape Accounting and Assessment. An Application to the Urban-Coastal Areas. In Proceedings of the 8th International Conference on Information and Communication Technologies in Agriculture, Food and Environment (HAICTA 2017), Chania, Greece, 21-24 September 2017; pp. 696-708.

68. Calabrò, F. Local Communities and Management of Cultural Heritage of the Inner Areas. An Application of Break-Even Analysis. In Computational Science and Its Applications-ICCSA 2017; Gervasi, O., Ed.; Lecture Notes in Computer Science; Springer: Cham, Switzerland, 2017.

69. Della Spina, L. Integrated Evaluation and Multi-methodological Approaches for the Enhancement of the Cultural Landscape. In ICCSA 2017. LNCS; Gervasi, O., Ed.; Springer: Cham, Switzerland, 2017.

(C) 2018 by the authors. Licensee MDPI, Basel, Switzerland. This article is an open access article distributed under the terms and conditions of the Creative Commons Attribution (CC BY) license (http:/ / creativecommons.org/licenses/by/4.0/). 